NBER WORKING PAPER SERIES

\title{
GOVERNMENT DEBT AND CORPORATE LEVERAGE: INTERNATIONAL EVIDENCE
}

\author{
Irem Demirci \\ Jennifer Huang \\ Clemens Sialm \\ Working Paper 23310 \\ http://www.nber.org/papers/w23310 \\ NATIONAL BUREAU OF ECONOMIC RESEARCH \\ 1050 Massachusetts Avenue \\ Cambridge, MA 02138 \\ April 2017
}

We thank Aydogan Alti, Miguel Ferreira, Adrien Matray, Kai Li, Vassil Mihov, Stijn Van Nieuwerburgh, Sheridan Titman, Garry Twite, Josef Zechner, and seminar participants at the 2015 FMA European Conference, the 2016 CEPR European Summer Symposium in Financial Markets, the 2016 China International Conference in Finance, the Frankfurt School of Finance and Management, the Nova School of Business and Economics, the University of Iowa, the University of Mannheim, the University of Texas at Austin, and the Vienna University of Economics and Business for comments and suggestions. Clemens Sialm is an independent contractor with AQR Capital Management. The views expressed herein are those of the authors and do not necessarily reflect the views of the National Bureau of Economic Research.

At least one co-author has disclosed a financial relationship of potential relevance for this research. Further information is available online at http://www.nber.org/papers/w23310.ack

NBER working papers are circulated for discussion and comment purposes. They have not been peer-reviewed or been subject to the review by the NBER Board of Directors that accompanies official NBER publications.

(C) 2017 by Irem Demirci, Jennifer Huang, and Clemens Sialm. All rights reserved. Short sections of text, not to exceed two paragraphs, may be quoted without explicit permission provided that full credit, including $\odot$ notice, is given to the source. 
Government Debt and Corporate Leverage: International Evidence

Irem Demirci, Jennifer Huang, and Clemens Sialm

NBER Working Paper No. 23310

April 2017

JEL No. F21,F34,F36,F65,G28,G32,G38,H63

\begin{abstract}
$\underline{\text { ABSTRACT }}$
We investigate the impact of government debt on corporate financing decisions. We document a negative relation between government debt and corporate leverage using data on 40 countries between 1990 and 2014. This negative relation holds only for government debt that is financed domestically and is stronger for larger and more profitable firms and in countries with more developed equity markets. In order to address potential endogeneity concerns, we use an instrumental variable approach based on military spending and a quasi-natural experiment based on the introduction of the Euro currency. Our findings suggest that government debt crowds out corporate debt.

Irem Demirci

University of Mannheim

L9, 1-2, Rm 303

68161 Mannheim

Germany

idemirci@mail.uni-mannheim.de

Jennifer Huang

Cheung Kong Graduate School of Business

1 East Chang An Avenue

Oriental Plaza, E2, 20F

Beijing, 100738

China

cyhuang@ckgsb.edu.cn

Clemens Sialm

University of Texas at Austin

McCombs School of Business

2110 Speedway; B6600

Austin, TX 78712-1276

and NBER

clemens.sialm@mccombs.utexas.edu
\end{abstract}




\section{Introduction}

Increasing government budget deficits and debt levels have obtained significant attention during the recent financial crisis. However, the impact of government debt on the corporate sector has not been explored much in the financial economics literature. Our paper investigates whether changes in government debt affect the financing choices of corporations in an international setting.

Government debt can crowd out corporate debt if investors in financial markets prefer to maintain a relatively stable proportion of debt and equity securities in their portfolios. An increase in government debt will increase the overall supply of debt in the economy. Households will only be willing to absorb the additional supply if debt securities offer higher expected returns. To the extent that it is not too costly for firms to deviate from their target capital structure, they will substitute some of the debt financing with equity to reduce overall financing costs.

We present a simple model where households can save using equity and debt securities. Households require a higher return for equity securities, as they have a preference for safer fixed-income securities. Firms finance their projects by issuing both debt and equity securities, whereas the government is constrained to only issue debt securities. The model shows that an increase in government debt increases the required returns on debt securities relative to equity securities, and thereby crowds out corporate debt financing. We also discuss the conditions that lead to differential crowding out effects across firms with different flexibilities to adjust their capital structures.

We empirically test the predictions of our theoretical model using a data set that covers 40 countries between 1990 and 2014. We find that higher levels of government debt are associated with lower corporate leverage levels. The results are robust to including country- and year-fixed effects, using alternative specifications based on changes in leverage levels, and controlling for various time-varying macroeconomic variables. We also obtain consistent results using a panel of disaggregated firm-level data.

We further investigate whether the relation between corporate debt and government 
debt depends on whether the government debt is financed domestically or internationally. Since corporate debt is largely held by domestic investors, we hypothesize that the crowding out effect is more pronounced for government debt purchased by domestic investors. Consistent with our hypothesis, we find an insignificant relation between external government debt and corporate debt. On the other hand, the coefficient estimates for domestic government debt are both statistically and economically significant.

The impact of government debt on capital structure might differ across firms within a country for several reasons. First, the debt of some firms (such as large firms and profitable firms) tends to be less risky and more liquid, so that those securities might be perceived as closer substitutes for government debt. Second, firms with more financial flexibility might incur lower costs of switching between debt and equity financing. These firms might be in a better position to adjust their capital structures in response to shocks in the supply of government securities. Consistent with our priors, we find that the crowding out effect is stronger for larger and more profitable firms.

Our international setting also allows us to study the impact of country characteristics on crowding out effects. We hypothesize that the cost of switching between debt and equity securities is smaller for firms operating in countries with more developed equity and bond markets. Our results indicate that a change in government debt has a stronger impact on corporate debt in countries with relatively large equity markets and in countries where companies are less dependent on bank financing.

An important concern about the crowding out effect of government debt is that government debt is endogenous. Firms might adjust their capital structures in response to economic conditions, which are correlated with the supply of government debt. ${ }^{1}$ We address this endogeneity concern using an instrumental variable approach and using a quasi-natural experiment. The first approach uses military expenditures as an instrument for the government budget deficit. Changes in military expenditures are, arguably, less affected by the economic environment than the overall budget deficit which is affected by changes in tax revenues and transfer payments. Our results remain robust using this in-

\footnotetext{
${ }^{1}$ The leverage dynamics of the business cycle is discussed by Hackbarth, Miao, and Morellec (2006), Bharma, Kuehn, and Strebulaev (2010), and Halling, Yu, and Zechner (2016).
} 
strumental variable approach. Our second approach addresses the potential endogeneity issues by utilizing the introduction of the Euro currency as a quasi-natural experiment. The European Monetary Union (EMU) facilitated the integration of financial markets in member countries. Companies and governments in EMU countries gained access to financing from a substantially broader market and became less dependent on domestic financing sources after the monetary unification. We find that the sensitivity of corporate leverage to local government debt decreased significantly for companies incorporated in EMU countries after the integration, whereas the corresponding sensitivity did not change for non-EMU countries.

Taggart (1986) investigates several macro factors that might explain the short- and long-run time-series variation in corporate debt. Analyzing U.S. data, he concludes that business risk, tax policy, and inflation risk fail to explain the short-run variation in corporate debt, whereas corporate debt is significantly related to government debt. Friedman (1986) argues that an increase in the supply of long-term government bonds will increase the expected return on government debt securities and on other securities that are close substitutes. Investors will attempt to trade out of these securities and trade into others like equity. He compares the response of spreads between debt and equity securities to changes in government debt, and finds that government debt financing decreases the spread between equity and debt securities.

In a more recent study, Greenwood, Hanson, and Stein (2010) develop a model that investigates the impact of government debt maturity on corporate debt maturity. When the supply of long-term Treasuries increases relative to the supply of short-term Treasuries, the expected return on long-term Treasuries increases. Firms absorb this supply shock by issuing short-term debt until the expected return differential between long-term and short-term debt is eliminated. They test the implications of their model using U.S. data and find a negative relation between corporate debt and government debt maturity. In a related study, Badoer and James (2016) argue that this gap filling is a more important determinant of very long-term corporate borrowing than shorter-term borrowing. Foley-Fisher, Ramcharan, and Yu (2014) examine the impact of the Federal Reserve's 
Maturity Extension Program (MEP) on the firm financial constraints. They find that firms that rely on long-term debt issued more long-term debt during the MEP's implementation. Furthermore, such firms enjoyed increases in investment and employment during the MEP relative to other periods, suggesting that the MEP affected real economic activity.

Krishnamurthy and Vissing-Jorgensen (2012, 2015) argue that investors value the liquidity and safety of U.S. Treasury bonds. An increase in the supply of government securities decreases the relative value of those attributes in the market. They find that an increase in the Treasury supply reduces the yield spread between Treasury and other fixed income securities. In addition, government debt crowds out the the supply of safe and liquid assets issued by other financial institutions, like bank-issued money (M2 minus M1) and other short-term debt. Our paper contributes to this literature by combining two substitution effects and deriving the equilibrium outcome: On the demand side investors substitute between government debt and corporate debt to meet their demand for safer assets and on the supply side firms substitute between debt and equity securities to minimize total financing costs.

Our paper is most related to Graham, Leary, and Roberts (2014), who investigate the government crowding out of corporate debt using unique long-term U.S. data from 1920-2012. They also find a robust negative relation between government leverage and corporate leverage. In a related paper, Ma (2016) finds that firms act as cross-market arbitrageurs in their own equity and debt securities and simultaneously issue in one market and repurchase in another in response to relative valuations. Our main contribution is to investigate the crowding out effect between government and corporate debt using a crosscountry sample. Using international data allows us to benefit from a larger variation in government debt and to take advantage of cross-country differences in institutional environments. Furthermore, our instrumental variable approach and the empirical analysis of the Euro integration also help to address potential endogeneity concerns.

In the corporate finance literature, a significant amount of research is devoted to understanding how firms make their financing decisions. Many of the empirical studies focus 
on the firm-specific determinants of capital structure. For instance, Titman and Wessels (1988) investigate the empirical validity of theoretical determinants of capital structure such as asset structure, growth, uniqueness, industry classification, size, earnings volatility, and profitability. Besides these firm-specific determinants, empirical studies show that there are also factors outside the firm, such as industry average leverage, peer firms' capital structures, and the economic environment that shape firms' leverage policies. ${ }^{2}$ A related literature has employed dynamic models to study the impact of taxes and financing frictions on capital structure, and the relation between investment, financing, and payout decisions. ${ }^{3}$ Finally, a growing literature uses the variation in the institutional environment across countries to explore the importance of country-specific factors. These papers provide an analysis of the impact of various institutional factors such as legal environment, tax policies, and the types of capital providers in the economy on capital structure. ${ }^{4}$ Our study contributes to these literatures by focusing on the impact of dynamic changes in government debt on firms' financing decisions in a large cross-country sample.

The remainder of the paper is organized as follows: Section 2 presents a simple model that formalizes the main ideas discussed in the Introduction. Section 3 describes the data and reports the summary statistics. Sections 4 and 5 present the results for country- and firm-level analysis, respectively. Section 6 investigates the cross-sectional differences in crowding out. Section 7 reports the crowding out results using instrumental variable specifications and using the EMU integration as a quasi-natural experiment.

\footnotetext{
${ }^{2}$ See for example, Korajczyk and Levy (2003), Welch (2004), Frank and Goyal (2007), Leary and Roberts (2014), and Graham, Leary, and Roberts (2015).

${ }^{3}$ See for example, Hennessy and Whited (2005), Strebulaev (2007), DeAngelo, DeAngelo, and Whited (2011), and DeAngelo and Roll (2015).

${ }^{4}$ See for example, Demirguc-Kunt and Maksimovic (1996, 1998, 1999), Booth, Aivazian, DemirgucKunt, and Maksimovic (2001), Claessens, Djankov, and Nenova (2000), Giannetti (2003), De Jong, Kabir, and Nguyen (2008), and Fan, Titman, and Twite (2012).
} 


\section{The Model}

We describe in this section a simple model that illustrates the crowding out effect. Our model includes three economic agents: households who save, firms who require financing to fund their projects, and the government.

\subsection{Households' Optimization Problem}

Households are endowed with an initial wealth of $W$, and decide how much to allocate to debt and equity securities in order to maximize the utility from next period's consumption:

$\max _{w_{D}, w_{G}} U\left[w_{D} W\left(1+r_{D}\right)+w_{G} W\left(1+r_{G}\right)+\left(1-w_{D}-w_{G}\right) W\left(1+r_{E}\right)+v\left(\rho w_{D}+w_{G}\right) W\right]$,

where $r_{D}, r_{G}$ and $r_{E}$ are returns on corporate debt, government debt and equity, and $w_{D} \equiv \frac{D}{W}, w_{G} \equiv \frac{G}{W}$ and $1-w_{D}-w_{G}$ are their portfolio weights. For simplicity, we do not explicitly model the risks of corporate debt and equity. The returns can be interpreted as risk-adjusted returns. We assume that households obtain additional utility $v$ from holding safer debt-like assets, where $v^{\prime}(\cdot) \geq 0, v^{\prime \prime}(\cdot) \leq 0$, and $U^{\prime}()>$.0 . The lower bound for the first derivative is given by $v^{\prime}(1)=0$ such that when $w_{D}=0$ and $w_{G}=1$, the additional utility obtained from holding more debt is zero. ${ }^{5}$ The parameter $\rho \in(0,1]$ captures the substitutability between corporate and government debt. As $\rho$ approaches one, households treat corporate debt as a perfect substitute for government debt. ${ }^{6}$

\footnotetext{
${ }^{5}$ When adjustment costs are low the equilibrium leverage ratio is above unity. We impose the following condition to keep the equilibrium leverage ratio below unity

$$
\theta>\frac{\rho v^{\prime}(0)}{1-\lambda}
$$

${ }^{6}$ The utility $v$ is similar to the preference for "extremely safe" assets, like bank deposits and Treasury bonds in Krishnamurthy and Vissing-Jorgensen (2015). We extend the preference to all debt-like instruments.
} 
The first-order conditions imply:

$$
\begin{gathered}
r_{E}-r_{D}=\rho v^{\prime}\left(\rho w_{D}+w_{G}\right), \\
r_{E}-r_{G}=v^{\prime}\left(\rho w_{D}+w_{G}\right) .
\end{gathered}
$$

The spread between the return on equity and debt securities captures in a reducedform the investors' preference for safer assets. The investors demand a higher return on corporate debt securities than government debt securities if the two security types are not perfect substitutes (i.e., $\rho<1$ ).

\subsection{Firms' Optimization Problem}

Firms have projects that require an investment of $K$ in the first period and produce an output of $f(K)$ in the second period. The total investment $K$ is financed by equity and debt, with leverage ratio $d \equiv \frac{D}{K}$. Each firm takes as a given the external financing costs $r_{D}$ and $r_{E}$, and chooses the leverage ratio $d$ to maximize total output net of financing and deviation costs:

$$
\max _{d} f(K)-d K\left(1+r_{D}\right)-(1-d) K\left(1+r_{E}\right)-\frac{\theta}{2}(d-\lambda)^{2} K
$$

The last term represents the quadratic costs for firms that deviate from the target capital structure $\lambda<1$. These costs capture the impact of various market frictions, such as taxes, agency costs, and other financing costs.

The firms' first-order condition is as follows:

$$
r_{E}-r_{D}=\theta(d-\lambda)
$$

The optimal leverage ratio is determined by equating the marginal cost of debt to marginal cost of equity. Firms choose the leverage ratio $d$ to take advantage of the rate differential $r_{E}-r_{D}$. This rate differential captures external capital market conditions that are 
unrelated to firm-specific risk.

\subsection{Market Equilibrium}

In equilibrium, both the equity and debt markets clear, and the outstanding amounts of equity and debt securities sum up to households' initial wealth:

$$
W=E+D+G=K+G .
$$

Substituting in the definitions of $w_{D}, w_{G}$ and $d$, we obtain the following relation between the households' portfolio share of debt and firms' leverage ratio:

$$
w_{D} \equiv \frac{D}{W}=\left(\frac{D}{K}\right)\left(\frac{K}{W}\right) \equiv d\left(1-w_{G}\right)
$$

Note that this equality holds for any levels of $G$ and $K$, and is independent of the relation between $K$ and $G$. We take as given the response of corporate investment $(K)$ to government debt $(G)$, and focus only on the financing decisions, namely the composition of investment between debt and equity.

By combining the two first-order conditions given in equations (1) and (3), and the definition of $w_{D}$ in (4), we derive the equilibrium condition

$$
\mu^{*} \equiv r_{E}^{*}-r_{D}^{*}=\theta\left(d^{*}-\lambda\right)=\rho v^{\prime}\left(\rho d^{*}\left(1-w_{G}\right)+w_{G}\right) .
$$

The equilibrium corporate debt level $d^{*}$ is determined by the households' preference for safer debt-like instruments, the supply of government debt, and the cost for firms to deviate from their target debt levels. The target $\lambda$ captures in a reduced form the optimal debt level for the firm, without taking into account the investors' preference for safe and liquid assets. The higher the cost of deviation $\theta$, the less a firm deviates from its target capital structure $\lambda .^{7}$

\footnotetext{
${ }^{7}$ In the Appendix A.1, we show that the equilibrium leverage ratio is above its target and that it decreases with $\theta$. Hence, higher financing costs are associated with leverage ratios that are closer to the target.
} 
Figure 1 depicts the equilibrium debt-to-capital ratio for the case without a government sector (i.e. $w_{G}=0$ ). The horizontal axis shows different leverage levels $d$ and the vertical axis shows the equity premium $r_{E}-r_{D}$. The preferences of households for debt securities are captured by the downward-sloping curve $\rho v^{\prime}(\rho d)$. As debt securities become more abundant, households do not require a large equity premium to be indifferent between holding equity and debt securities. The upward-sloping line $\theta(d-\lambda)$ captures the capital structure preferences of firms. At a leverage ratio of $d=\lambda$, the frictions of debt financing are minimized. However, due to households' preference for debt-like securities, the return that households demand for holding equity is higher than for debt at $d=\lambda$ by an amount of $\rho v^{\prime}(\rho \lambda)$. Therefore, the firm increases its leverage from the target level $\lambda$ to $d^{*}$ where the marginal cost of debt financing equals the marginal benefit of holding debt for the household. The figure shows that the equilibrium level of debt-to-capital $\left(d^{*}\right)$ corresponds to a positive equity premium.

\section{$<$ Figure 1 about here $>$}

The following result derives the impact of government debt on the corporate leverage ratio.

Proposition 1: Given households' preference for debt-like instruments, an increase in government debt leads to a lower corporate leverage ratio and a lower equity premium.

Appendix A.2 presents the detailed proof. We can also prove by contradiction that both $d^{*}$ and $w_{D}^{*}$ should decrease after the introduction of government debt. Assume counterfactually that $d^{*}$ increases with $w_{G}$. Then, equation (5) implies that $v^{\prime}$ increases. Since $v^{\prime \prime}() \leq 0,. v^{\prime}$ increases only if $\rho w_{D}^{*}+w_{G}$ decreases. Given the increase in $w_{G}, \rho w_{D}^{*}$ has to decrease more than the increase in $w_{G}$. Since $\rho w_{D}^{*}=\rho d^{*}\left(1-w_{G}\right)$ and $\rho d^{*} \leq 1$, every percentage point increase in $w_{G}$ decreases $\rho w_{D}^{*}$ by less than one percentage point, holding $d^{*}$ constant. Hence, the only feasible equilibrium response is for both $d^{*}$ and $w_{D}^{*}$ to decrease when government debt increases.

Figure 2 shows how the introduction of government debt affects the equilibrium in financial markets. We compare the equilibrium outcomes without a government sector 
(denoted with one asterisk) and with a government sector (denoted with two asterisks). The introduction of government debt shifts the marginal utility curve $\left(v^{\prime}\right)$ downwards because the household sector now has a larger share of debt securities for a given portfolio share of corporate debt. Households demand a higher return on corporate debt if the firm keeps its leverage ratio at its initial level $d^{*}$ which in turn increases the total cost of debt financing for the firm. Hence, the firm decreases its leverage ratio to the point where the marginal cost of debt is equal to the marginal cost of equity. The introduction of government debt reduces both the equity premium and the optimal amount of corporate debt.

\section{$<$ Figure 2 about here $>$}

\subsection{Firms with Different Financing Frictions}

Next, we investigate whether the crowding out effect differs between firms with different financing frictions. We use the cost of deviating from the optimal capital structure $(\theta)$ as a measure of financing frictions. We assume that the substitutability between corporate debt is identical across firms (i.e., $\rho$ is identical). In an integrated market, the equity premia $\left(\mu=r_{E}-r_{D}\right)$ need to be identical across firms given that their debt securities are perceived as identical by households.

The firms' first order condition (3) implies the following equity premia with $\left(\mu^{* *}\right)$ and without $\left(\mu^{*}\right)$ the government sector for $i \in\{L, H\}$ :

$$
\mu^{*}=\theta_{i}\left(d_{i}^{*}-\lambda\right) \text { and } \mu^{* *}=\theta_{i}\left(d_{i}^{* *}-\lambda\right) .
$$

By taking the difference between the equity premia we obtain the following equalities for firms with high and low financing frictions:

$$
\mu^{*}-\mu^{* *}=\theta_{H}\left(d_{H}^{*}-d_{H}^{* *}\right)=\theta_{L}\left(d_{L}^{*}-d_{L}^{* *}\right) .
$$


Firms with higher costs to deviate from their target leverage ratio will tend to change their leverage levels to a smaller extent than firms with lower financial frictions:

$$
\frac{d_{H}^{*}-d_{H}^{* *}}{d_{L}^{*}-d_{L}^{* *}}=\frac{\theta_{L}}{\theta_{H}}<1
$$

Proposition 2: The introduction of government debt yields a smaller change in leverage for firms with higher financing frictions.

Figure 3 illustrates how an increase in the supply of government debt affects the leverage for firms that are subject to different levels of financing frictions but with the same level of substitutability. In equilibrium, the two firms have the same equity premia since the households are indifferent between holding the securities of the two firms. The decrease in the equity premium generated by the introduction of government debt decreases the leverage ratios of the two firms. Higher financing frictions captured by $\theta$ are associated with a lower sensitivity of the leverage ratio to changes in the equity premium. Therefore, in response to the same amount of decrease in equity premium, high- $\theta$ firms optimally choose smaller adjustments in their leverage ratios compared to low- $\theta$ firms.

\footnotetext{
$<$ Figure 3 about here $>$
}

\section{$3 \quad$ Data and Summary Statistics}

This section describes the data sources and summarizes the main variables used in our empirical analysis.

\subsection{Data}

We obtain firm-level accounting data from Compustat Global and Compustat North America, and firm-level market data from Compustat Global Security Daily. The main variable of interest is the total government debt-to-GDP ratio, which we obtain from 
the World Economic Outlook (WEO) database available through the $\mathrm{IMF}^{8}$. For other country-level variables, we use data from the World Bank, IMF and the ECB. To ensure that the country-level variables are consistently defined over time, for each country and variable, we use the data source that provides us with the longest series.

Our sample covers the period between 1990 and 2014, and the first year of the sample is determined by the availability of the firm-level and country-level data which varies across countries. Observations with missing and/or negative book value of assets are dropped from the sample. We exclude financial (6000-6999), public (9000-9999), and utility (4900-4999) firms. Since we focus on the time-series variation in corporate and public debt, each firm is required to have data on book leverage, lagged firm-level controls, as well as lagged values of government debt, GDP per capita, inflation, S\&P index level, unemployment, and nominal exchange rate. ${ }^{9}$ The final sample consists of 38,776 firms from 40 countries with a total of 343,403 firm-year observations and 813 country-year observations.

Table 1 shows the distribution of countries in our sample. The sample includes firms from different parts of the world, mainly Europe, Asia, North America, and South America. The U.S., Japan, and the U.K. are the countries with the highest number of firm-year observations.

\section{$<$ Table 1 about here $>$}

\footnotetext{
${ }^{8}$ The WEO series are not available for the earlier periods of our sample for some countries. For those countries with short series we use government debt data from the central banks whenever available or other sources such as World Bank. Those countries are Ireland, Israel, Peru, South Africa, and the US.

${ }^{9}$ We also exclude country-year observations with less than ten firms and 16 country-year observations with a sovereign debt default or restructuring event. These events are associated with large decreases and increases in government debt-to-GDP ratios that might result from significant devaluations of the local currency, changes in external debt policy or debt forgiveness. We obtain the data on sovereign debt defaults and restructuring episodes from Carmen M. Reinhart and Kenneth S. Rogoff's webpage at http: //www.reinhartandrogoff.com/.
} 


\subsection{Summary Statistics}

We use three leverage measures for our firm-level analyses. First, we define the traditional leverage measures, Book Leverage and Market Leverage, which are total book debt over book value of assets and total book debt over market value of assets, respectively. The third measure, Debt-to-Capital Ratio, proposed by Welch (2011), is defined as the book value of debt divided by debt plus the book value of equity. ${ }^{10}$ The book value of total assets includes the value of non-financial liabilities such as trade credit, in addition to book debt and book equity. Therefore, an increase in accounts payable causes a decrease in the book leverage, even if total financial debt of the firm stays constant. The debt-to-capital ratio is immune to such changes in non-financial liabilities. The countrylevel variables follow firm-level definitions, and are calculated by aggregating the values in the numerator and the denominator over all firms in a given year and country. We require positive book values of equity for our debt-to-capital ratio and market-to-book ratio calculations. All ratio variables, including leverage measures, are winsorized at the top and bottom $1 \%$.

Table 2 reports country averages for corporate leverage and macroeconomic variables. While, on average, firms in Hong Kong have the lowest book leverage, firms in Portugal have the highest book leverage in our sample. Belgium, Greece, Italy, and Japan are countries with an average government debt-to-GDP ratio exceeding 100\%. Chile, Hong Kong, and Russia have the lowest average government debt-to-GDP ratios that are all below $20 \%$.

\section{$<$ Table 2 about here $>$}

Besides our main country-level debt variables, we also control for other country characteristics. Our main specification includes GDP per capita, the level of consumer prices, the level of equity prices, the exchange rate, and the unemployment rate. In order to

\footnotetext{
${ }^{10}$ Besides these three leverage measures, we also estimated our regressions for Net Leverage which is defined as total debt minus cash normalized by total assets. Our results also hold for net leverage.
} 
account for the movements in the stock market, we convert each country's return on its S\&P Global Equity Index into a variable that tracks the index level assuming that the base year is the first year in the sample. The nominal exchange rate is the value of the local currency relative to one U.S. dollar calculated as an annual rate based on monthly averages. The unemployment rate is defined as the number of unemployed relative to the labor force.

We also compute additional firm-level variables that have been shown to relate to corporate leverage (Rajan and Zingales (1995), Baker and Wurgler (2002), Frank and Goyal (2003), and Lemmon, Roberts, and Zender (2008)). The tangibility is defined as the ratio between the value of property, plant, and equipment (PPE) and total assets. We use the book value of total assets to account for the impact of firm size on leverage. The return on assets $(R O A)$ is defined as operating income scaled by total assets. Finally, the market-to-book ratio is defined as the ratio between the market value of total assets and the book value of the firm. We use Compustat currency exchange rate data in order to convert non-ratio variables into U.S. dollars. Detailed variable definitions are given in Table A1 of the Appendix.

Panels A and B of Table 3 report the summary statistics for country- and firm-level variables, respectively. Panel A of Table 3 shows that the ratio between corporate debt and corporate total assets has a mean (median) of $28.3 \%$ (27.7\%) and a standard deviation of $6.5 \%$. Since it is normalized by the book value of total capital rather than total assets, the debt-to-capital ratio is higher than the book leverage, with a mean (median) of $42.3 \%$ (42.0\%). On average, the market leverage is smaller than the other leverage measures with a mean of $19.5 \%$ and a median of $18.5 \%$. The government debt-to-GDP ratio has a mean of $58.3 \%$ and an interquartile range of $37.2 \%$ and $72.5 \%$. There is a significant difference between the variances of domestic and external government debt such that the standard deviation of external government debt is almost twice as high as the standard deviation of domestic debt. The median GDP per capita amounts to $\$ 24,407$ and the average unemployment rate is $7.4 \%$.

$<$ Table 3 about here $>$ 
Panel B reports the summary statistics for firm-level variables. On average, the book leverage, the debt-to-capital ratio, and the market leverage are $21.7 \%, 29.7 \%$ and $18.0 \%$, respectively. Consistent with the capital structure literature, we find a significant variation in the tangibility of firms. The mean tangibility equals $30.5 \%$ with an interquartile range between $11.2 \%$ and $44.6 \%$. Most firms in our sample are profitable, as captured by a median ROA of $8.4 \%$. Finally, the median firm's market value exceeds the book value by $24.2 \%$.

\section{Country-Level Analysis}

This section presents the results of our empirical analyses using the country panel where we aggregate firm-level variables by year and country.

\subsection{Fixed Effects Specification}

Our first proposition states that an increase in government debt leads to a reduction in corporate leverage. We test this hypothesis both in levels and changes of government debt. Our baseline specification relates the country-level corporate debt to government debt-to-GDP ratio and additional macro variables. More specifically, we estimate the following regression equation:

$$
\begin{aligned}
\text { Leverage }_{j, t}=\beta_{1} \text { Government Debt-to-GDP }_{j, t-1} & \\
& +\beta_{2} X_{j, t-1}+\beta_{3} Y_{j, t-1}+u_{j}+\delta_{t}+\varepsilon_{j, t} .
\end{aligned}
$$

Equation (6) is estimated separately for three different definitions of Leverage $_{j, t}$, namely book leverage, market leverage, and the debt-to-capital ratio. Government Debt-to $-G D P_{j, t-1}$ is total government debt as a percentage of GDP in country $j ; X_{j, t-1}$ denotes macro variables, including the natural logarithm of GDP per capita, the natural logarithm of consumer prices, the natural logarithm of the equity index, the natural logarithm 
of the exchange rate, and the unemployment rate; $Y_{j, t-1}$ denotes the traditional determinants of leverage that are averaged across firms within a country, namely tangibility, firm size, profitability, and the market-to-book ratio. Finally, $u_{j}$ and $\delta_{t}$ denote countryand year-fixed effects, respectively. Year-fixed effects account for worldwide events such as the recent financial crisis, and country-fixed effects control for time-invariant country characteristics.

Panel A of Table 4 reports the results for the fixed effects specification. The standard errors are clustered at the country level and $t$-statistics are reported in parentheses. The results indicate a negative relation between government debt and aggregate corporate leverage. A 10 percentage point increase in government debt relative to GDP reduces book leverage (market leverage) by $0.74(0.55)$ percentage points. Government debt is also negatively correlated with the debt-to-capital ratio: a 10 percentage point increase in government debt-to-GDP is associated with a 0.96 percentage point decrease in the debt-to-capital ratio. Alternatively, a one standard deviation increase in government debt relative to GDP reduces book leverage (market leverage) by 0.38 (0.23) standard deviations. The exchange rate, the unemployment rate, and the ROA are significant determinants of the book leverage.

\section{$<$ Table 4 about here $>$}

\subsection{First Differences Specification}

A second method for analyzing the time-series relation between corporate debt and government debt is to estimate equation (6) in first differences:

$$
\begin{aligned}
\text { Leverage }_{j, t, t-1}= & \beta_{1} \Delta \text { Government Debt-to-GDP }_{j, t-1, t-2} \\
& +\beta_{2} \Delta X_{j, t-1, t-2}+\beta_{3} \Delta Y_{j, t-1, t-2}+\delta_{t}+\varepsilon_{j, t} .
\end{aligned}
$$

Panel B of Table 4 reports the results for country-level first differences regressions. The coefficient estimates for the government debt-to-GDP ratio are all negative for our 
three different leverage measures such that corporate leverage decreases significantly following an increase in government debt. For example, a 10 percentage points increase in the government debt-to-GDP ratio is associated with a $0.68(0.59)$ percentage points decrease in firm book leverage (market leverage) in the subsequent year. The economic magnitude in the first differences specification is very similar to the magnitude in the fixed effects specification. The coefficients on the log-transformed variables in the first differences specification capture the impact of the prior-year growth rates in the corresponding variables on the changes in the corporate leverage levels. Note that changes in the GDP per capita, the ROA, and the market-to-book ratio are typically significantly related to changes in corporate debt. Overall, our findings suggest that there is a negative relation between corporate leverage and government debt supply. ${ }^{11}$

\subsection{External versus Domestic Government Debt}

Our government debt variable includes both external and domestic government debt. Consequently, there can be cases in which an increase in the supply of government debt is absorbed by foreign investors or international financial institutions leaving more local funds available for corporations. We should therefore expect a stronger relation between corporate leverage and domestically-held debt. In Table 5 we repeat our baseline analysis by replacing Government Debt-to-GDP with Domestic Government Debt and External Government Debt measured in percent of GDP. ${ }^{12}$ Domestic government debt is calculated by subtracting external government debt from total government debt outstanding. The results are reported for both fixed effects and first differences specifications. For all leverage definitions, the economic magnitude of the estimates for the coefficient of internal government debt is larger than the estimates for total government debt reported in Table

\footnotetext{
${ }^{11}$ In order to ensure that the results are not driven by a single country in our sample, we repeat the fixed effects and first differences regressions in Table 4 by dropping one country at a time from our sample. We also estimated our baseline specification for the period before the 2007 financial crisis. Our results are robust to these subsamples.

${ }^{12}$ The IMF defines gross external debt as, at any given time, the outstanding amount of those actual current, and not contingent, liabilities that require payment(s) of principal and/or interest by the debtor at some point(s) in the future and that are owed to nonresidents by residents of an economy (http: //www.imf .org/external/pubs/ft/eds/Eng/Guide/file2.pdf).
} 
$4{ }^{13}$ Furthermore, the coefficient estimates for external debt are insignificant suggesting that the negative relation between corporate leverage and government leverage is driven by domestic public debt rather than external debt.

\section{$<$ Table 5 about here $>$}

\subsection{Constant Elasticity Specification}

One possible concern about using the government debt-to-GDP ratio as the independent variable is that the relation between corporate leverage and government debt could be driven by changes in GDP rather than changes in the amount of government debt outstanding. To address this concern, we regress the natural logarithm of the dollar value of corporate debt on the natural logarithm of the dollar value of lagged government debt. The coefficients in this specification can be interpreted as the elasticities of corporate debt in response to changes in government debt. Table 6 reports the estimation results which confirm our findings in Table 4. The elasticity of corporate debt with respect to government debt is between 0.145 and 0.198 depending on whether we use a fixed effects or a first differences specification.

\section{$<$ Table 6 about here $>$}

\subsection{OECD Countries}

We repeat our baseline estimation for the subsample of countries that are members of the OECD. ${ }^{14}$ Panel A of Table A2 in the Appendix reports the fixed effects regression

\footnotetext{
${ }^{13}$ This result is not an artifact of the different samples in Tables 4 and 5 . We continue to find the coefficient estimates for domestic government debt to be higher than those for total government debt in the smaller sample.

${ }^{14}$ Those countries are: Austria, Australia, Belgium, Canada, Denmark, Germany, Finland, France, Greece, Ireland, Italy, Japan, South Korea, Mexico, Netherlands, Norway, New Zealand, Poland, Portugal, Spain, Sweden, Switzerland, Turkey, the U.S., and the U.K. Since they became members in 2010, Chile and Israel are not included in the OECD sample.
} 
results for the 25 OECD countries. The results are similar to those reported for the whole sample. In Panel B, we repeat our baseline first differences analysis for the OECD countries. Consistent with the fixed effects regression results, the coefficient estimates for the OECD subsample are similar to those estimated for the whole sample.

\section{$5 \quad$ Firm-Level Analysis}

We estimate in this section our model using firm-level data. Using firm-level data allows us to control for firm-specific determinants of leverage and mitigates concerns about the composition of firms changing in the country sample. Furthermore, the firm-level analysis weighs more heavily towards countries with a larger number of firm observations.

Panels A and B of Table 7 report the estimation results for firm-fixed effects and the first difference specifications, respectively. All independent variables are lagged by one year relative to leverage. Standard errors are clustered at the country level. We obtain a negative relation between the level of government debt and firm leverage levels for all three leverage measures. The coefficient estimates imply that a 10 percentage point increase in government debt relative to GDP reduces firm leverage by between 0.46 and 0.74 percentage points. Similarly, the coefficient estimates from the first differences specification are consistent with our previous findings. A 10 percentage point change in government debt relative to GDP reduces firm leverage by between 0.78 and 1.04 percentage points. Consistent with the capital structure literature, we find that book leverage variables increase with tangibility of assets and firm size, and decrease with the ROA and the market-to-book ratio.

\section{$<$ Table 7 about here $>$}

We conduct several robustness tests for our firm-level analysis which we report in the Appendix. As we did for the country panel, in the firm panel, we restrict the sample to the OECD member countries. Fixed effects and first differences estimation results 
for this subsample are reported in Table A3, which are similar to those for the baseline specification in Table 7.

We also differentiate between domestic and external government debt at the firm level. The results are reported in Table A4 which confirm the findings from the country-level analysis: domestic debt is more significantly related to leverage rather than total debt.

Next, we investigate whether the negative impact of government debt on corporate leverage is specific to long-term or short-term corporate debt. In Table A5, we estimate our baseline specification for long-term debt defined as total debt that matures in more than one year divided by total assets, and for short-term debt defined as the ratio of debt in current liabilities to total assets. The results indicate that the negative relation holds for both long-term and short-term corporate debt.

\section{Cross-Sectional Differences in Crowding Out}

This section studies whether the relation between corporate debt and government debt differs across firms and across countries.

\subsection{Firm Characteristics and Crowding Out}

We investigate the impact of firm characteristics on the crowding out effect, as discussed in Proposition 2. The impact of government debt on capital structure might differ across firms for two reasons. First, firms with more financial flexibility incur lower costs of switching between debt and other sources of financing. These firms are in a better position to adjust their capital structure in response to shifts in demand. For example, larger firms are more flexible in their choices between debt and equity financing, since they are potentially less subject to asymmetric information problems. In contrast, high equity issuance costs or borrowing costs might prevent small firms from changing their method of financing. Similarly, more profitable firms face lower costs in adjusting their capital structure because they have the flexibility of first drawing down their internal 
funds before tapping the external capital market. Moreover, they may face a lower cost of switching between debt and equity financing. Second, some types of corporate debt are closer substitutes to government debt than others. For example, bonds issued by larger firms might be more liquidly traded. Similarly, more profitable firms tend to have lower default risk, which makes their debt a better substitute for government debt. Thus, the crowding out effect should be stronger for large and profitable firms. Therefore, larger and more profitable firms should respond more to government debt changes.

In the first three columns of Table 8 we interact the government debt-to-GDP ratio with an indicator variable for firm size. More specifically, we split firms into two groups depending on whether their lagged total book value of assets is in the top 20th percentile of their country-year distribution. On average, these firms constitute $80 \%$ of the total market value of equity in their countries. Consistent with our prior, we find that the crowding out effect is significantly higher for large firms than for small firms.

\section{$<$ Table 8 about here $>$}

Similarly, we expect profitable firms to respond more to changes in government debt. Such firms are more likely to have high retained earnings that they can use towards investment without any need for external financing. The last three columns of Table 8 report the results for profitability interactions, where the dummy variable Profitable indicates that the firm's lagged ROA is above its country's median in a given year. The results show that the crowding out effect is more significant for profitable firms. Overall, we find consistent evidence with our model's implications such that government crowding out is more prominent for firms that are financially less constrained.

\subsection{Country Characteristics and Crowding Out}

In this section, we investigate the cross-country variation in the crowding out effect. We hypothesize that in countries where firms are eligible for alternative sources of external financing, it is less costly for firms to adjust their capital structure. Consequently, we 
expect corporate debt to respond more to changes in government debt in such countries relative to others.

We define two proxies, namely, the bank dependence of the private sector and the size of the equity market to test cross-country variation in crowding out. Bank Dependence is measured by the outstanding amount of bank credit extended to the private sector as a fraction of GDP. Carlin and Mayer (2003) use this variable to measure the bank dependence of industries. Market Capitalization is defined as the total market value of public firms as a percent of GDP. This variable is used to measure stock market development by Levine and Zervos (1998), and to measure the ease of access to stock market by Beck, Lundberg, and Majnoni (2006). In each year, we split the sample into two equally-sized groups based on previous year's Market Capitalization and Bank Dependence. The indicator variables High Bank Dependence and Low Market Capitalization capture country-year observations with above-median bank dependence and below-median market capitalization, respectively.

Table 9 reports the estimation results using the country-level regressions. All regressions include year- and country-fixed effects as well as the interactions of High Bank Dependence and Low Market Capitalization with the control variables which are not reported to save space. The coefficient estimates for government debt-to-GDP are all negative indicating that corporate leverage is negatively related to government debt-toGDP ratio in countries with relatively large equity markets and less bank dependent private sectors. On the other hand, the positive coefficient estimates of the interaction terms suggest that the crowding out effect is less prominent in countries with relatively small equity markets and more bank dependent economies. ${ }^{15}$

\section{$<$ Table 9 about here $>$}

\footnotetext{
${ }^{15}$ We obtain similar results when we define Bank Dependence as bank credit divided by book value of corporate assets.
} 


\section{$7 \quad$ Endogeneity Concerns}

An important concern about the crowding out effect of government debt is that government debt is endogenous. Firms might adjust their capital structure in response to economic conditions, which are correlated with the supply of government debt. We address this endogeneity concern in multiple ways. As mentioned previously, our specifications include year-fixed effects that capture the impact of the global business cycle and additionally control for several country-level macroeconomic variables that capture the local business environment. Furthermore, we only find a crowding out effect for the portion of government debt that is financed domestically, confirming the postulated segmentation of debt markets. In this section we present further evidence to address potential endogeneity concerns. We first present the results from an instrumental variable specification and then we discuss results that use the EMU integration as a quasi-natural experiment.

\subsection{Instrumental Variable Approach}

Although we control for time-invariant country characteristics, various macroeconomic controls, and year-fixed effects in our baseline analysis, endogeneity concerns might remain. For example, government budget deficits tend to be large when the economy is performing poorly. In these periods the government receives lower tax revenues and has higher transfer expenditures from various social programs (e.g., unemployment benefits, welfare). Such episodes might also coincide with time periods where corporations are more financially constrained and adjust their financing strategies. We address this issue by employing an instrumental variable approach where we use military expenditures as an instrument for government debt. ${ }^{16}$ While military expenditures are not completely exogenous, they are less affected by the macro-economic environment than other government

\footnotetext{
${ }^{16}$ Ramey and Shapiro (1998) use large military buildups and increases in total purchases as exogenous changes in government spending. Berndt, Lustig, and Yeltekin (2012) identify fiscal shocks as innovations to current and future defense spending growth.
} 
revenues and expenditures, such as taxes and transfer payments.

Panel A of Table 10 reports the estimation results where the government debt-to-GDP ratio is instrumented with the lagged military expenditures relative to GDP. In order to ensure that our results are not driven by firms operating in defense related industries, we drop firms in industries that are at least 40 percent defense dependent, as determined by the U.S. Bureau of Labor Statistics. ${ }^{17}$

We use the lag of military expenditures to mitigate the possibility of reverse causality. The first stage estimation results indicate that there is a positive and statistically significant relation between military expenditures and government debt. Panel A also reports the statistics for underidentification and weak identification tests. The Kleibergen-Paap LM statistic is 4.60 with a $p$-value of 0.032 , which rejects the null of underidentification at the $5 \%$ level. The Kleibergen-Paap F statistic amounts to 4.48 , which is below the rule of thumb value of 10 .

The second stage regressions indicate a significant relation between corporate leverage and instrumented government debt. The results for the government debt-to-GDP are broadly consistent with those in Table 4 .

\section{$<$ Table 10 about here $>$}

Panel B reports the results for domestic government debt, which are based on a smaller sample due to data availability. We continue to find a statistically significant negative relation between our leverage measures and domestic government debt in the second stage. Both the first stage and the second stage coefficient estimates increase in statistical significance relative to Panel A. Furthermore, the Kleibergen-Paap LM and the Kleibergen-Paap F statistics increase to $7.28(p=0.007)$ and to 10.84 , respectively.

\footnotetext{
${ }^{17}$ These industries are explosives, ordnance and accessories, radio and TV communications equipment, communications equipment, aircraft and parts, shipbuilding and repairing, guided missiles and space vehicles, tanks and tank components, search and navigation equipment, commercial physical research, commercial nonphysical research, and testing laboratories.
} 


\subsection{Euro-Area Integration}

In this section we use the integration of the bond markets in the European Monetary Union (EMU) as a quasi-natural experiment to address the endogeneity concerns. Since the second half of the 1990s, the degree of integration in various European financial markets has significantly increased (ECB, 2006). The effect has especially been prominent in government and corporate bond markets (Pagano and Von Thadden, 2004 and ECB, 2006).

We hypothesize that after the EMU integration, the sensitivity of corporate leverage to local government debt decreases for companies incorporated in one of the EMU countries. The monetary integration can weaken the crowding out effect through increased demand by non-local investors for government debt and corporate debt securities. While the former helps local investors in absorbing government debt supply and increases funds available to the corporate sector, the latter decreases firms' dependence on local investors, especially on financial institutions.

Figure 4 depicts the relation between changes in corporate leverage and changes in the government debt-to-GDP ratio for EMU and non-EMU countries before (1990-1998) and after the introduction of the Euro (1999-2006). Whereas the relation between corporate leverage and government debt is negative for non-EMU countries both before and after the integration, the negative relation for EMU countries completely disappears after the Euro integration.

\section{$<$ Figure 4 about here $>$}

Next, we verify the finding in Figure 4 using a regression specification. Table 11 analyzes the impact of the EMU integration on the sensitivity of corporate leverage to government debt. After 1998 is an indicator variable for the years following 1998. The sample period ranges from 1990 to 2006. EMU is an indicator variable that captures whether the country is a member of the European Monetary Union. All regressions include macroeconomic and firm-level controls as well as their interactions with the $E M U$, 
After 1998, and EMU X After 1998. In order to save space, we only report the coefficient estimates for government debt and its interactions. All regressions include the direct effects of EMU, After 1998, and EMU X After 1998.

Panel A in Table 11 reports the fixed effects regression results for book leverage, debtto-capital, and market leverage. All regressions include country-fixed effects. Consistent with our baseline specification, the coefficient estimates of government debt before 1999 for non-EMU countries are negative, and they are statistically significant at the $1 \%$ level. The positive coefficient estimates for the triple interactions suggest that corporate leverage becomes less sensitive to local government debt in EMU countries after the integration. The results are statistically significant for the book and the market leverage regressions. The results also indicate that there is no significant change in the government debt sensitivity of corporate debt after 1998 for non-EMU countries.

\section{$<$ Table 11 about here $>$}

In Panel B, we repeat our analysis using the first differences specification. In all specifications, the change in government debt-to-GDP is negative and significant at least at a $5 \%$ level. Finally, the coefficient estimates of the triple interaction term are positive in all specifications and statistically significant in two of the three specifications.

\section{Conclusions}

In this paper, we investigate the impact of government debt on firms' capital structure decisions using data on 40 countries between 1990-2014. We argue that an increase in government debt supply might reduce investors' demand for corporate debt relative to equity since government debt is a better substitute for corporate debt than for equity. As a result, corporations might adjust their capital structure and reduce their leverage. We document a negative relation between government debt and corporate leverage both in levels and changes of debt after controlling for country- and year-fixed effects as well as 
country-level controls. We find that the crowding out effect is stronger for firms and countries facing smaller financing frictions, for example for larger and more profitable firms or for firms in countries with more developed equity markets and less bank-dependent private sectors. These firms tend to have more flexibility in substituting between different sources of financing. In order to address potential endogeneity problems, we use an instrumental variable approach and a quasi-natural experiment based on the EMU integration. Overall, our results are consistent with government debt crowding out corporate debt. 


\section{References}

Badoer, D.C. and James, C.M., 2016. The determinants of long-term corporate debt issuances. The Journal of Finance, 71(1), 457-492.

Baker, M. and Wurgler, J., 2002. Market timing and capital structure. The Journal of Finance, 57(1), 1-32.

Beck, T., Lundberg, M. and Majnoni, G., 2006. Financial intermediary development and growth volatility: Do intermediaries dampen or magnify shocks? Journal of International Money and Finance, 25(7), 1146-1167.

Berndt, A., Lustig, H. and Yeltekin, S., 2012. How does the US government finance fiscal shocks? American Economic Journal: Macroeconomics, 4(1), 69-104.

Bhamra, H.S., Kuehn, L.A. and Strebulaev, I.A., 2010. The aggregate dynamics of capital structure and macroeconomic risk. Review of Financial Studies, 23, 4187-4241.

Booth, L., Aivazian, V., Demirguc-Kunt, A. and Maksimovic, V., 2001. Capital structures in developing countries. The Journal of Finance, 56, 87-130.

Carlin, W. and Mayer, C., 2003. Finance, investment, and growth. Journal of Financial Economics, 69(1), 191-226.

Claessens, S., Djankov, S. and Nenova, T., 2000. Corporate Risk around the World. SSRN Working Paper.

DeAngelo, H., DeAngelo, L. and Whited, T.M., 2011. Capital structure dynamics and transitory debt. Journal of Financial Economics, 99(2), 235-261.

DeAngelo, H. and Roll, R., 2015. How stable are corporate capital structures?. The Journal of Finance, 70(1), 373-418.

De Jong, A., Kabir, R. and Nguyen, T.T., 2008. Capital structure around the world: The roles of firm- and country-specific determinants. Journal of Banking and Finance, 32, 1954-1969. 
Demirgüç-Kunt, A. and Maksimovic, V., 1996. Stock market development and financing choices of firms. The World Bank Economic Review, 10(2), 341-369.

Demirgüç-Kunt, A. and Maksimovic, V., 1998. Law, finance, and firm growth. The Journal of Finance, 53(6), 2107-2137.

Demirgüç-Kunt, A. and Maksimovic, V., 1999. Institutions, financial markets, and firm debt maturity. Journal of Financial Economics, 54(3), 295-336.

European Central Bank, 2006. Indicators of financial integration in the Euro area. Available at https://www.ecb.europa.eu/pub/pdf/other/indicatorsfinancialintegration200609en.pdf

Fan, J.P., Titman, S. and Twite, G., 2012. An international comparison of capital structure and debt maturity choices. Journal of Financial and Quantitative Analysis, 47(01), $23-56$.

Foley-Fisher, N., Ramcharan, R. and Yu, E.G., 2014. The impact of unconventional monetary policy on firm financing constraints: Evidence from the maturity extension program. SSRN Working Paper.

Frank, M.Z. and Goyal, V.K., 2003. Testing the pecking order theory of capital structure. Journal of Financial Economics, 67(2), 217-248.

Frank, M.Z., and Goyal, V.K., 2007. Trade-off and pecking order theories of debt. In Espen Eckbo ed.: Handbook of Corporate Finance: Empirical Corporate Finance.

Friedman, B.M., 1986. Implications of government deficits for interest rates, equity returns, and corporate financing. In Financing Corporate Capital Formation. University of Chicago Press, 67-90.

Giannetti, M., 2003. Do better institutions mitigate agency problems? Evidence from corporate finance choices. Journal of Financial and Quantitative Analysis, 38, 185212.

Graham, J.R., Leary, M.T. and Roberts, M.R., 2014. How does government borrowing affect corporate financing and investment? NBER Working Paper 20581. 
Graham, J.R., Leary, M.T. and Roberts, M.R., 2015. A century of capital structure: The leveraging of corporate America. Journal of Financial Economics, 118(3), 658-683.

Greenwood, R., Hanson, S. and Stein, J.C., 2010. A gap-filling theory of corporate debt maturity choice. The Journal of Finance, 65(3), 993-1028.

Hackbarth, D., Miao, J. and Morellec, E., 2006. Capital structure, credit risk, and macroeconomic conditions. Journal of Financial Economics, 82, 519-550.

Halling, M., Yu, J. and Zechner, J., 2016. Leverage dynamics over the business cycle. Journal of Financial Economics, 122, 21-41.

Hennessy, C.A. and Whited, T.M., 2005. Debt dynamics. The Journal of Finance, 60(3), 1129-1165.

Korajczyk, R.A. and Levy, A., 2003. Capital structure choice: Macroeconomic conditions and financial constraints. Journal of Financial Economics, 68(1), 75-109.

Krishnamurthy, A. and Vissing-Jorgensen, A., 2012. The aggregate demand for Treasury debt. Journal of Political Economy, 120(2), 233-267.

Krishnamurthy, A. and Vissing-Jorgensen, A., 2015. The impact of Treasury supply on financial sector lending and stability. Journal of Financial Economics, 118(3), 571-600.

Leary, M.T. and Roberts, M.R., 2014. Do peer firms affect corporate financial policy? The Journal of Finance, 69(1), 139-178.

Lemmon, M.L., Roberts, M.R. and Zender, J.F., 2008. Back to the beginning: Persistence and the cross-section of corporate capital structure. The Journal of Finance, 63(4), $1575-1608$

Levine, R. and Zervos, S., 1998. Stock markets, banks, and economic growth. American Economic Review, 88(3), 537-558.

Ma, Y., 2016. Non-financial firms as cross-market arbitrageurs. SSRN Working Paper. 
Pagano, M. and Von Thadden, E.L., 2004. The European bond markets under EMU. Oxford Review of Economic Policy, 20(4), 531-554.

Rajan, R.G. and Zingales, L., 1995. What do we know about capital structure? Some evidence from international data. The Journal of Finance, 50(5), 1421-1460.

Ramey, V.A. and Shapiro, M.D., 1998. Costly capital reallocation and the effects of government spending. In Carnegie-Rochester Conference Series on Public Policy, 48, 145-194.

Strebulaev, I.A., 2007. Do Tests of Capital Structure Theory Mean What They Say? The Journal of Finance, 62 (4), 1747-1787.

Taggart Jr, R., 1986. Have US corporations grown financially weak? In Financing corporate capital formation. University of Chicago Press, 13-34.

Titman, S. and Wessels, R., 1988. The determinants of capital structure. The Journal of Finance, 43 (1), 1-19.

Welch, I., 2004. Capital structure and stock returns. Journal of Political Economy, 112(1), $106-132$

Welch, I., 2011. Two common problems in capital structure research: The financial debt to asset ratio and issuing activity versus leverage changes. International Review of Finance, 11(1), 1-17. 


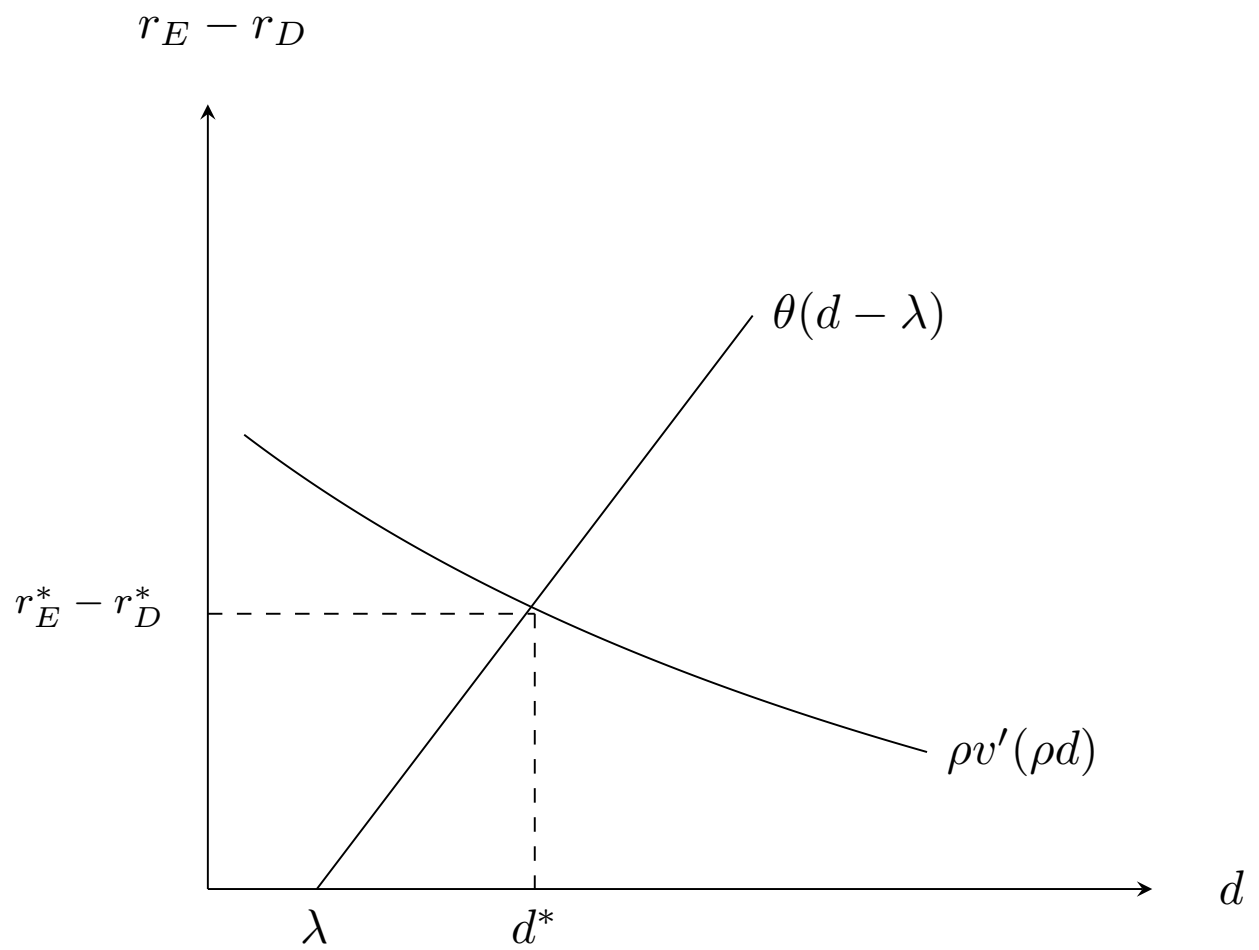

Figure 1: Baseline model This figure shows the equilibrium level of debt-to-capital ratio $\left(d^{*}\right)$ for the baseline case without government sector.

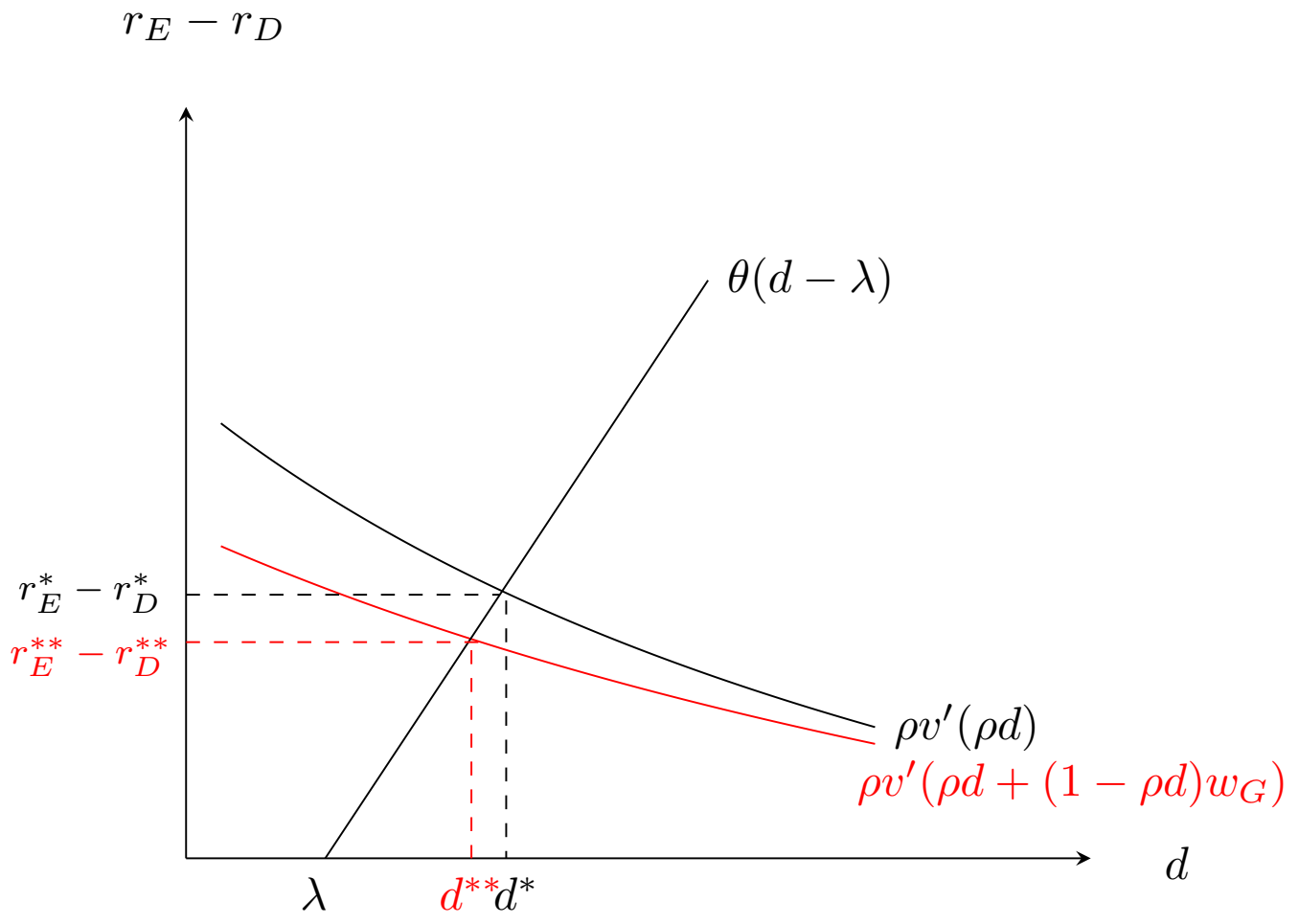

Figure 2: Government sector This figure shows the impact of government debt on the equilibrium level of debt-to-capital ratio $(d)$ for corporations. 


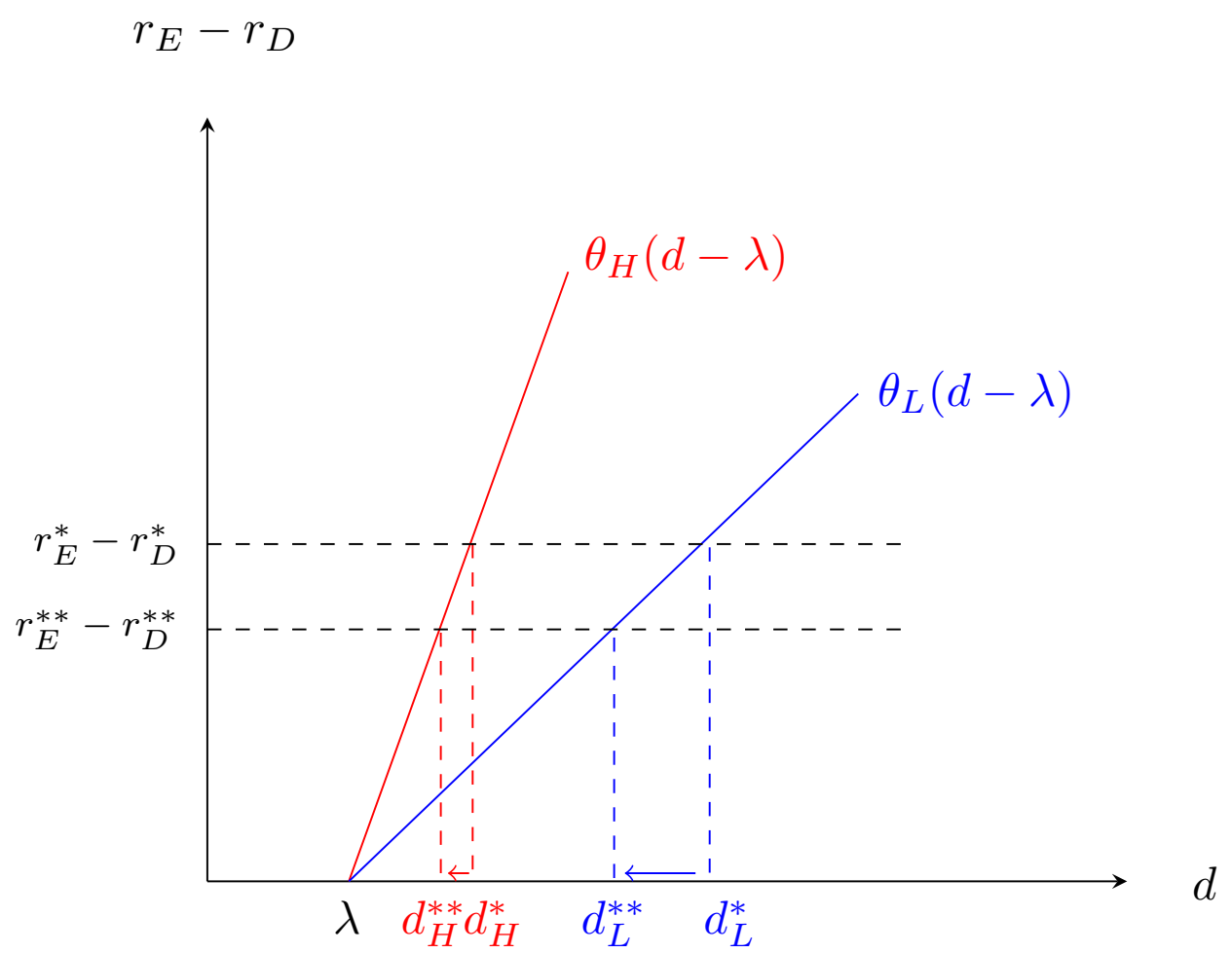

Figure 3: Two firms with different financing frictions This figure shows the impact of the introduction of government sector on the equilibrium level of debt-to-capital ratio for two firms with different levels of financing frictions. 


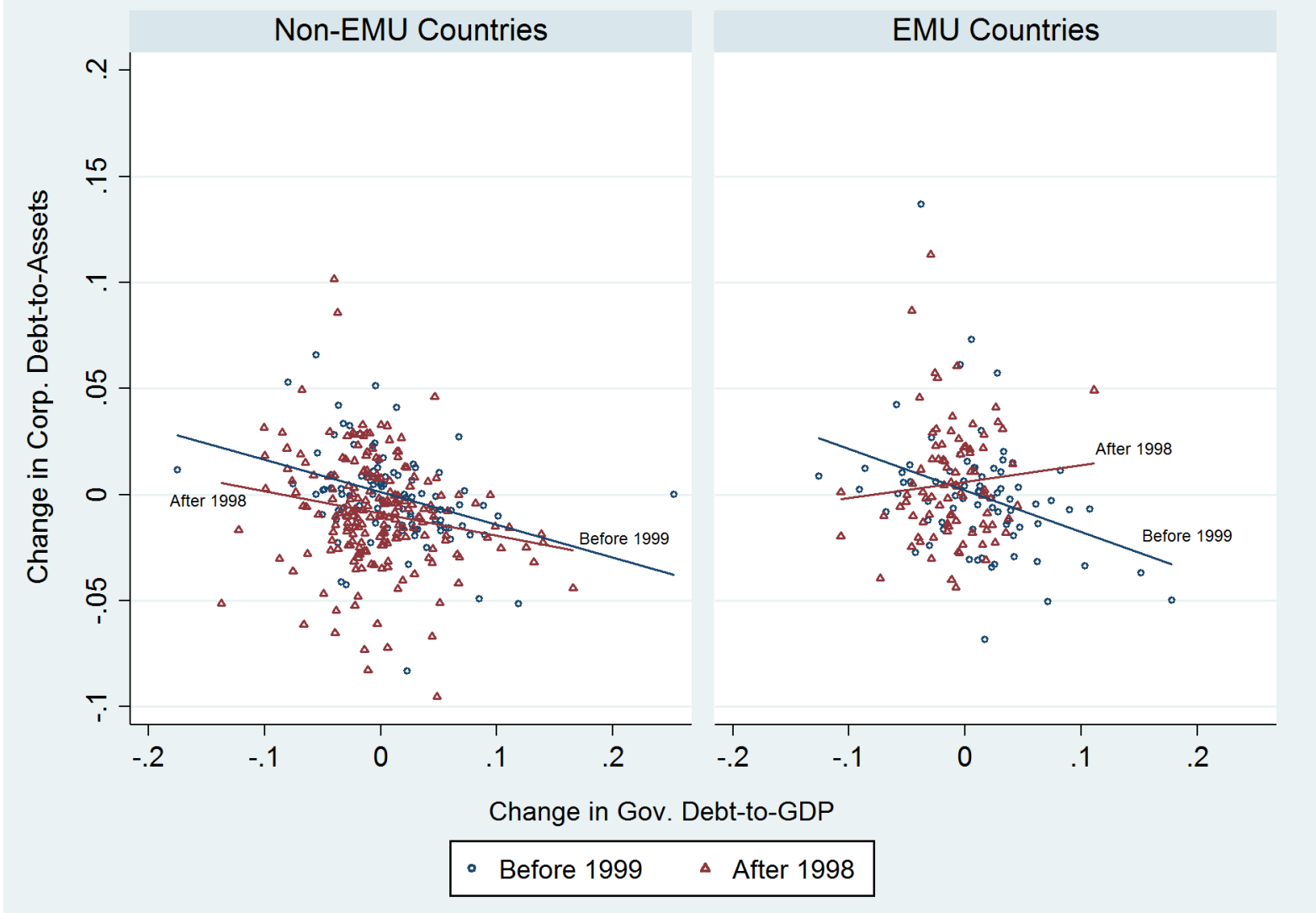

Figure 4: EMU Integration This figure depicts scatter plots of $\Delta$ Government Debt-to$\operatorname{GDP}_{t-1, t-2}$ and $\Delta$ Book Leverage $_{t, t-1}$ in countries that are members of the EMU and all other countries over the 17-year period around the integration (1990-2006). The lines represent the linear regression fits before 1999 and after 1998. 


\section{Table 1: Sample Distribution}

This table reports the frequency distribution of countries in our sample.

\begin{tabular}{|c|c|c|c|c|c|}
\hline Country & $\begin{array}{r}\text { Number of } \\
\text { Years }\end{array}$ & $\begin{array}{r}\text { Number of } \\
\text { Firms }\end{array}$ & $\begin{array}{l}\text { Number of } \\
\text { Observations }\end{array}$ & Minimum & Maximum \\
\hline Argentina & 8 & 57 & 266 & 1998 & 2014 \\
\hline Australia & 25 & 1,986 & 16,390 & 1990 & 2014 \\
\hline Austria & 25 & 116 & 1,173 & 1990 & 2014 \\
\hline Belgium & 25 & 140 & 1,525 & 1990 & 2014 \\
\hline Brazil & 13 & 230 & 1,472 & 2001 & 2014 \\
\hline Canada & 25 & 2,927 & 20,202 & 1990 & 2014 \\
\hline Chile & 18 & 136 & 1,292 & 1997 & 2014 \\
\hline China & 19 & 2,343 & 17,209 & 1996 & 2014 \\
\hline Denmark & 22 & 186 & 1,878 & 1993 & 2014 \\
\hline Finland & 25 & 152 & 1,881 & 1990 & 2014 \\
\hline France & 25 & 939 & 9,247 & 1990 & 2014 \\
\hline Germany & 23 & 884 & 8,805 & 1992 & 2014 \\
\hline Greece & 17 & 231 & 2,219 & 1997 & 2014 \\
\hline Hong Kong & 13 & 127 & 1,243 & 2002 & 2014 \\
\hline India & 19 & 2,451 & 14,743 & 1996 & 2014 \\
\hline Indonesia & 12 & 360 & 2,578 & 2002 & 2014 \\
\hline Ireland & 25 & 93 & 911 & 1990 & 2014 \\
\hline Israel & 17 & 344 & 2,145 & 1998 & 2014 \\
\hline Italy & 25 & 303 & 2,941 & 1990 & 2014 \\
\hline Japan & 25 & 3,821 & 53,437 & 1990 & 2014 \\
\hline Malaysia & 19 & 978 & 10,659 & 1996 & 2014 \\
\hline Mexico & 18 & 116 & 1,153 & 1997 & 2014 \\
\hline Netherlands & 25 & 240 & 2,676 & 1990 & 2014 \\
\hline New Zealand & 23 & 145 & 1,285 & 1992 & 2014 \\
\hline Norway & 25 & 291 & 2,300 & 1990 & 2014 \\
\hline Peru & 15 & 72 & 609 & 2000 & 2014 \\
\hline Philippines & 19 & 155 & 1,526 & 1996 & 2014 \\
\hline Poland & 18 & 433 & 2,881 & 1997 & 2014 \\
\hline Portugal & 20 & 77 & 703 & 1995 & 2014 \\
\hline Russia & 13 & 156 & 953 & 2002 & 2014 \\
\hline Singapore & 24 & 700 & 6,951 & 1991 & 2014 \\
\hline South Africa & 19 & 344 & 3,243 & 1996 & 2014 \\
\hline South Korea & 19 & 1,478 & 9,432 & 1996 & 2014 \\
\hline Spain & 23 & 171 & 1,842 & 1992 & 2014 \\
\hline Sweden & 21 & 568 & 4,427 & 1994 & 2014 \\
\hline Switzerland & 25 & 243 & 3,084 & 1990 & 2014 \\
\hline Thailand & 18 & 507 & 5,223 & 1997 & 2014 \\
\hline Turkey & 13 & 237 & 1,851 & 2001 & 2014 \\
\hline United Kingdom & 25 & 2,522 & 22,421 & 1990 & 2014 \\
\hline United States & 25 & 11,517 & 98,627 & 1990 & 2014 \\
\hline Total & 813 & 38,776 & 343,403 & 1990 & 2014 \\
\hline
\end{tabular}




\section{Table 2: Summary Statistics by Country}

This table shows the summary statistics for the country-level variables. Book Leverage is defined as the ratio of total book debt of all firms in a country to sum of their assets. Debt-to-Capital is the ratio of total corporate debt to total corporate capital (book value of debt plus equity) in each country. Market Leverage is defined as the ratio of total book debt of all firms in a country to their market value of assets. Government Debt is gross government debt divided by GDP, GDP Per Capita is measured in current U.S. dollars, Unemployment is measured as a proportion of the labor force, and Exchange Rate is denoted in local currency units per U.S. dollar. $\operatorname{Ln}(S \xi B P$ Index) and $\operatorname{Ln}($ CPI Level) are calculated by taking the natural logarithm of the level of S\&P Global Equity Index and the level of CPI.

\begin{tabular}{|c|c|c|c|c|c|c|c|c|c|}
\hline Country & $\begin{array}{r}\text { Book } \\
\text { Leverage }\end{array}$ & $\begin{array}{l}\text { Debt-to- } \\
\text { Capital }\end{array}$ & $\begin{array}{r}\text { Market } \\
\text { Leverage }\end{array}$ & $\begin{array}{c}\text { Gov. Debt } \\
\text { to GDP }\end{array}$ & $\begin{array}{r}\operatorname{Ln}(\text { GDP } \\
\text { Per Capita) }\end{array}$ & $\operatorname{Ln}(\mathrm{CPI})$ & $\begin{array}{r}\operatorname{Ln}(\mathrm{S} \& \mathrm{P} \\
\text { Index })\end{array}$ & $\begin{array}{r}\text { Unemploy- } \\
\text { ment }\end{array}$ & $\begin{array}{r}\text { Ln(Exchange } \\
\text { Rate })\end{array}$ \\
\hline Argentina & 0.27 & 0.36 & 0.19 & 0.39 & 9.19 & 5.08 & 5.08 & 0.11 & 0.72 \\
\hline Australia & 0.27 & 0.38 & 0.18 & 0.21 & 10.24 & 5.02 & 5.25 & 0.07 & 0.29 \\
\hline Austria & 0.25 & 0.43 & 0.21 & 0.67 & 10.37 & 4.88 & 4.80 & 0.05 & 0.87 \\
\hline Belgium & 0.28 & 0.45 & 0.21 & 1.12 & 10.32 & 4.89 & 5.21 & 0.08 & 1.30 \\
\hline Brazil & 0.31 & 0.44 & 0.06 & 0.66 & 8.80 & 22.21 & 5.81 & 0.08 & 0.75 \\
\hline Canada & 0.27 & 0.39 & 0.20 & 0.84 & 10.27 & 4.93 & 5.17 & 0.08 & 0.22 \\
\hline Chile & 0.28 & 0.37 & 0.22 & 0.11 & 8.94 & 6.03 & 4.83 & 0.08 & 6.27 \\
\hline China & 0.26 & 0.36 & 0.22 & 0.34 & 7.50 & 5.59 & 4.96 & 0.04 & 2.03 \\
\hline Denmark & 0.27 & 0.39 & 0.17 & 0.51 & 10.64 & 4.94 & 5.64 & 0.07 & 1.82 \\
\hline Finland & 0.29 & 0.44 & 0.18 & 0.42 & 10.36 & 4.92 & 5.73 & 0.09 & 0.51 \\
\hline France & 0.27 & 0.48 & 0.20 & 0.61 & 10.28 & 4.88 & 5.15 & 0.09 & 0.58 \\
\hline Germany & 0.26 & 0.49 & 0.20 & 0.61 & 10.38 & 4.92 & 5.54 & 0.08 & 0.05 \\
\hline Greece & 0.31 & 0.45 & 0.24 & 1.11 & 9.86 & 5.93 & 5.35 & 0.12 & 1.52 \\
\hline Hong Kong & 0.17 & 0.23 & 0.09 & 0.01 & 10.30 & 5.33 & 6.28 & 0.05 & 2.05 \\
\hline India & 0.33 & 0.46 & 0.24 & 0.73 & 6.58 & 5.81 & 5.27 & 0.04 & 3.79 \\
\hline Indonesia & 0.32 & 0.43 & 0.19 & 0.37 & 7.57 & 6.62 & 4.25 & 0.08 & 9.15 \\
\hline Ireland & 0.33 & 0.46 & 0.18 & 0.68 & 10.30 & 4.96 & 5.34 & 0.10 & -0.29 \\
\hline Israel & 0.34 & 0.51 & 0.23 & 0.80 & 10.07 & 5.96 & 5.40 & 0.08 & 1.39 \\
\hline Italy & 0.30 & 0.53 & 0.26 & 1.08 & 10.17 & 5.10 & 4.79 & 0.09 & 2.81 \\
\hline Japan & 0.32 & 0.49 & 0.26 & 1.48 & 10.47 & 4.72 & 3.93 & 0.04 & 4.70 \\
\hline Malaysia & 0.28 & 0.38 & 0.21 & 0.42 & 8.64 & 5.09 & 4.16 & 0.03 & 1.22 \\
\hline Mexico & 0.30 & 0.43 & 0.21 & 0.43 & 8.89 & 6.87 & 5.70 & 0.04 & 2.36 \\
\hline Netherlands & 0.25 & 0.44 & 0.15 & 0.63 & 10.40 & 4.88 & 5.47 & 0.05 & 0.13 \\
\hline New Zealand & 0.32 & 0.41 & 0.17 & 0.30 & 9.96 & 4.96 & 4.67 & 0.06 & 0.48 \\
\hline Norway & 0.30 & 0.46 & 0.23 & 0.37 & 10.80 & 4.93 & 5.12 & 0.04 & 1.90 \\
\hline Peru & 0.24 & 0.31 & 0.19 & 0.36 & 8.10 & 15.85 & 5.66 & 0.08 & 1.14 \\
\hline Philippines & 0.35 & 0.47 & 0.28 & 0.53 & 7.24 & 5.83 & 3.87 & 0.09 & 3.76 \\
\hline Poland & 0.22 & 0.31 & 0.18 & 0.46 & 8.92 & 10.19 & 5.32 & 0.13 & 1.20 \\
\hline Portugal & 0.39 & 0.59 & 0.29 & 0.70 & 9.69 & 5.41 & 5.22 & 0.09 & 1.14 \\
\hline Russia & 0.20 & 0.24 & 0.16 & 0.19 & 8.82 & 11.82 & 5.37 & 0.07 & 3.37 \\
\hline Singapore & 0.22 & 0.32 & 0.13 & 0.85 & 10.22 & 4.86 & 5.14 & 0.03 & 0.44 \\
\hline South Africa & 0.20 & 0.30 & 0.11 & 0.39 & 8.44 & 5.96 & 4.85 & 0.24 & 1.92 \\
\hline South Korea & 0.33 & 0.51 & 0.31 & 0.23 & 9.68 & 5.36 & 4.74 & 0.04 & 6.99 \\
\hline Spain & 0.35 & 0.56 & 0.23 & 0.56 & 9.94 & 5.19 & 5.35 & 0.16 & 1.56 \\
\hline Sweden & 0.25 & 0.38 & 0.13 & 0.51 & 10.55 & 5.02 & 5.78 & 0.08 & 2.03 \\
\hline Switzerland & 0.25 & 0.38 & 0.15 & 0.52 & 10.82 & 4.87 & 5.75 & 0.03 & 0.25 \\
\hline Thailand & 0.37 & 0.49 & 0.25 & 0.44 & 8.01 & 5.27 & 3.42 & 0.02 & 3.57 \\
\hline Turkey & 0.25 & 0.35 & 0.18 & 0.49 & 8.92 & 12.51 & 6.01 & 0.10 & 0.34 \\
\hline United Kingdom & 0.22 & 0.35 & 0.13 & 0.49 & 10.27 & 5.00 & 5.25 & 0.07 & -0.50 \\
\hline United States & 0.28 & 0.42 & 0.16 & 0.68 & 10.50 & 5.00 & 5.54 & 0.06 & 0.00 \\
\hline Total & 0.28 & 0.42 & 0.19 & 0.58 & 9.68 & 6.02 & 5.15 & 0.07 & 1.68 \\
\hline
\end{tabular}


Table 3: Summary Statistics for Country- and Firm-Level Variables

This table shows the summary statistics for the country-level (Panel A) and firm-level (Panel B) variables. We use three leverage measures for our firm-level analyses. Book Leverage and Market Leverage are total debt over book value of assets and total debt over market value of assets, respectively. Debt-to-Capital is the ratio of total corporate debt to total corporate capital (book value of debt plus equity) in each country. Tangibility is defined as the ratio between the value of property, plant, and equipment (PPE) and total assets. We use the natural logarithm of book value of total assets (Ln(Assets)) in order to account for the impact of firm size on leverage. Return on assets $(R O A)$ is defined as operating income scaled by total assets. Finally, Market-to-Book is defined as the ratio between the market value and the book value of total assets. Country-level corporate variables are calculated by aggregating the numerator and the denominator over all firms with non-missing dependent and control variables in a given year and country. Domestic Government Debt is total debt net of debt owed to nonresidents. All country-level ratio variables and all firm-level ratio variables are winsorized at $1 \%$ on both ends of the distribution.

Panel A: Country-Level Variables

\begin{tabular}{|c|c|c|c|c|c|c|}
\hline & Mean & Std. Dev. & 25th Perc. & Median & 75th Perc. & Num. Obs. \\
\hline Book Leverage & 0.283 & 0.065 & 0.239 & 0.277 & 0.318 & 813 \\
\hline Debt-to-Capital & 0.423 & 0.098 & 0.359 & 0.420 & 0.481 & 813 \\
\hline Market Leverage & 0.195 & 0.079 & 0.140 & 0.185 & 0.237 & 813 \\
\hline Gov. Debt-to-GDP & 0.583 & 0.335 & 0.372 & 0.527 & 0.725 & 813 \\
\hline Domestic Gov. Debt-to-GDP & 0.204 & 0.169 & 0.080 & 0.167 & 0.292 & 671 \\
\hline External Gov. Debt-to-GDP & 0.380 & 0.301 & 0.190 & 0.307 & 0.513 & 671 \\
\hline Ln(GDP Per Capita) & 9.684 & 1.118 & 9.145 & 10.048 & 10.477 & 813 \\
\hline Ln(CPI Index Level) & 6.019 & 2.900 & 4.881 & 5.094 & 5.633 & 813 \\
\hline Ln(S\&P Index Level) & 5.146 & 0.795 & 4.605 & 5.183 & 5.714 & 813 \\
\hline Ln(Exchange Rate) & 1.680 & 2.162 & 0.030 & 1.118 & 2.311 & 813 \\
\hline Unemployment Rate & 0.074 & 0.045 & 0.043 & 0.068 & 0.091 & 813 \\
\hline Tangibility & 0.405 & 0.108 & 0.329 & 0.403 & 0.477 & 813 \\
\hline $\operatorname{Ln}($ Assets $)$ & 12.092 & 1.595 & 10.936 & 11.983 & 13.134 & 813 \\
\hline ROA & 0.126 & 0.033 & 0.103 & 0.121 & 0.146 & 813 \\
\hline Market-to-Book & 1.780 & 2.071 & 1.232 & 1.470 & 1.795 & 813 \\
\hline
\end{tabular}

Panel B: Firm-Level Variables

\begin{tabular}{lcccccc}
\hline & Mean & Std. Dev. & 25th Perc. & Median & 75th Perc. & Num. Obs. \\
\hline Book Leverage & & & & & & \\
Debt-to-Capital & 0.217 & 0.205 & 0.034 & 0.184 & 0.340 & 343,403 \\
Market Leverage & 0.297 & 0.253 & 0.049 & 0.270 & 0.483 & 336,487 \\
Tangibility & 0.180 & 0.179 & 0.019 & 0.131 & 0.289 & 330,249 \\
Ln(Assets) & 0.305 & 0.232 & 0.112 & 0.261 & 0.446 & 343,403 \\
ROA & 5.101 & 2.088 & 3.724 & 5.070 & 6.424 & 343,403 \\
Market-to-Book & 0.042 & 0.253 & 0.025 & 0.084 & 0.141 & 343,403 \\
\hline
\end{tabular}




\section{Table 4: Baseline Specification (Country Panel)}

Panel A and Panel B report the estimation results for the fixed effects and first differences specifications, respectively. Leverage denotes one of the following debt measures: Book Leverage is defined as the ratio of total book debt of all firms in a country to their total assets; Debt-to-Capital is the ratio of total corporate debt to total corporate capital (book value of debt plus equity) in each country; and Market Leverage is defined as the ratio of total book debt of all firms in a country to their market value of assets. All other variables are explained in Tables 2 and 3. All regressions include year-fixed effects. Standard errors are clustered at the country level. Statistical significance at the $10 \%, 5 \%$ and $1 \%$ levels are denoted by "**, "**" and "***", respectively.

\begin{tabular}{|c|c|c|c|c|c|c|}
\hline & \multicolumn{3}{|c|}{ Panel A: Fixed Effects } & \multicolumn{3}{|c|}{ Panel B: First Differences } \\
\hline & $\begin{array}{c}\text { Book } \\
\text { Leverage }\end{array}$ & $\begin{array}{c}\text { Debt-to- } \\
\text { Capital }\end{array}$ & $\begin{array}{l}\text { Market } \\
\text { Leverage }\end{array}$ & $\begin{array}{c}\text { Book } \\
\text { Leverage }\end{array}$ & $\begin{array}{l}\text { Debt-to- } \\
\text { Capital }\end{array}$ & $\begin{array}{c}\text { Market } \\
\text { Leverage }\end{array}$ \\
\hline Gov. Debt-to-GDP ${ }_{t-1}$ & $\begin{array}{l}-0.074^{* * *} \\
(-3.523)\end{array}$ & $\begin{array}{l}-0.096^{* * *} \\
(-2.984)\end{array}$ & $\begin{array}{l}-0.055^{* *} \\
(-2.277)\end{array}$ & $\begin{array}{l}-0.068^{* * *} \\
(-3.211)\end{array}$ & $\begin{array}{l}-0.109^{* * *} \\
(-3.611)\end{array}$ & $\begin{array}{c}-0.059^{*} \\
(-1.837)\end{array}$ \\
\hline Ln(GDP Per Capita $\left.{ }_{t-1}\right)$ & $\begin{array}{c}0.014 \\
(0.646)\end{array}$ & $\begin{array}{c}0.048^{*} \\
(1.926)\end{array}$ & $\begin{array}{c}0.029 \\
(0.998)\end{array}$ & $\begin{array}{c}0.031^{* *} \\
(2.189)\end{array}$ & $\begin{array}{c}0.046^{* *} \\
(2.265)\end{array}$ & $\begin{array}{c}0.042^{*} \\
(1.957)\end{array}$ \\
\hline $\operatorname{Ln}\left(\right.$ CPI Index Level $\left.{ }_{t-1}\right)$ & $\begin{array}{c}0.017 \\
(0.645)\end{array}$ & $\begin{array}{c}0.030 \\
(0.878)\end{array}$ & $\begin{array}{c}-0.020 \\
(-0.506)\end{array}$ & $\begin{array}{c}-0.034 \\
(-1.007)\end{array}$ & $\begin{array}{c}-0.047 \\
(-0.816)\end{array}$ & $\begin{array}{c}-0.021 \\
(-0.353)\end{array}$ \\
\hline $\operatorname{Ln}\left(\mathrm{S} \& \mathrm{P}\right.$ Index Level $\left.{ }_{t-1}\right)$ & $\begin{array}{c}-0.016 \\
(-1.326)\end{array}$ & $\begin{array}{c}-0.032^{*} \\
(-1.984)\end{array}$ & $\begin{array}{l}-0.049^{* * *} \\
(-3.635)\end{array}$ & $\begin{array}{c}-0.004 \\
(-0.839)\end{array}$ & $\begin{array}{c}-0.003 \\
(-0.393)\end{array}$ & $\begin{array}{c}-0.011 \\
(-1.346)\end{array}$ \\
\hline Ln(Exchange Rate Re- $\left._{t-1}\right)$ & $\begin{array}{l}-0.014^{* * *} \\
(-3.660)\end{array}$ & $\begin{array}{c}-0.014^{*} \\
(-2.021)\end{array}$ & $\begin{array}{l}-0.013^{* * *} \\
(-3.584)\end{array}$ & $\begin{array}{c}-0.002 \\
(-0.993)\end{array}$ & $\begin{array}{c}-0.001 \\
(-0.237)\end{array}$ & $\begin{array}{c}-0.003 \\
(-1.118)\end{array}$ \\
\hline 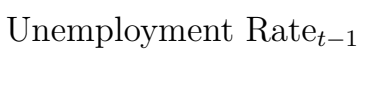 & $\begin{array}{l}0.266^{* * *} \\
(2.914)\end{array}$ & $\begin{array}{c}0.322^{* *} \\
(2.417)\end{array}$ & $\begin{array}{c}0.130 \\
(1.157)\end{array}$ & $\begin{array}{c}-0.104 \\
(-1.213)\end{array}$ & $\begin{array}{c}-0.074 \\
(-0.594)\end{array}$ & $\begin{array}{c}-0.099 \\
(-0.729)\end{array}$ \\
\hline Tangibility $_{t-1}$ & $\begin{array}{c}0.048 \\
(0.645)\end{array}$ & $\begin{array}{c}-0.062 \\
(-0.591)\end{array}$ & $\begin{array}{c}0.139 \\
(1.605)\end{array}$ & $\begin{array}{c}0.005 \\
(0.095)\end{array}$ & $\begin{array}{c}-0.077 \\
(-0.989)\end{array}$ & $\begin{array}{c}-0.030 \\
(-0.474)\end{array}$ \\
\hline $\operatorname{Ln}\left(\right.$ Assets $\left._{t-1}\right)$ & $\begin{array}{c}-0.001 \\
(-0.151)\end{array}$ & $\begin{array}{c}0.006 \\
(0.611)\end{array}$ & $\begin{array}{c}-0.010 \\
(-1.095)\end{array}$ & $\begin{array}{c}-0.000 \\
(-0.068)\end{array}$ & $\begin{array}{c}0.005 \\
(0.646)\end{array}$ & $\begin{array}{c}0.013^{* *} \\
(2.188)\end{array}$ \\
\hline $\mathrm{ROA}_{t-1}$ & $\begin{array}{l}-0.812^{* * *} \\
(-5.541)\end{array}$ & $\begin{array}{l}-1.171^{* * *} \\
(-5.659)\end{array}$ & $\begin{array}{l}-1.055^{* * *} \\
(-4.235)\end{array}$ & $\begin{array}{c}-0.148^{* *} \\
(-2.179)\end{array}$ & $\begin{array}{c}-0.187^{*} \\
(-1.943)\end{array}$ & $\begin{array}{c}-0.142 \\
(-1.216)\end{array}$ \\
\hline Market-to-Book ${ }_{t-1}$ & $\begin{array}{c}-0.000 \\
(-0.108)\end{array}$ & $\begin{array}{c}0.003^{*} \\
(1.902)\end{array}$ & $\begin{array}{l}-0.007^{* * *} \\
(-2.790)\end{array}$ & $\begin{array}{c}-0.001^{* *} \\
(-2.498)\end{array}$ & $\begin{array}{l}-0.001^{* * *} \\
(-2.905)\end{array}$ & $\begin{array}{c}-0.003^{* *} \\
(-2.071)\end{array}$ \\
\hline Observations & 813 & 813 & 813 & 780 & 780 & 780 \\
\hline Adj. R-squared & 0.697 & 0.748 & 0.712 & 0.188 & 0.191 & 0.389 \\
\hline Year FE & YES & YES & YES & YES & YES & YES \\
\hline Country FE & YES & YES & YES & $\mathrm{NO}$ & $\mathrm{NO}$ & $\mathrm{NO}$ \\
\hline
\end{tabular}




\section{Table 5: Domestic vs. External Debt (Country Panel)}

This table investigates the impact of external government debt on corporate leverage by repeating the baseline fixed effects and the first differences specifications after decomposing Government Debt-to-GDP as Domestic Government Debt and External Government Debt measured in percent of GDP. External Government Debt is government debt owed to nonresidents. Domestic Government Debt is Government Debt-to-GDP net of external debt. Standard errors are clustered at the country level. Statistical significance at the $10 \%, 5 \%$ and $1 \%$ levels are denoted by "**", "**" and "***", respectively.

\begin{tabular}{|c|c|c|c|c|c|c|}
\hline & \multicolumn{3}{|c|}{ Panel A: Fixed Effects } & \multicolumn{3}{|c|}{ Panel B: First Differences } \\
\hline & $\begin{array}{c}\text { Book } \\
\text { Leverage }\end{array}$ & $\begin{array}{c}\text { Debt-to- } \\
\text { Capital }\end{array}$ & $\begin{array}{l}\text { Market } \\
\text { Leverage }\end{array}$ & $\begin{array}{c}\text { Book } \\
\text { Leverage }\end{array}$ & $\begin{array}{c}\text { Debt-to- } \\
\text { Capital }\end{array}$ & $\begin{array}{l}\text { Market } \\
\text { Leverage }\end{array}$ \\
\hline Domestic Gov. Debt $t_{t-1}$ & $\begin{array}{l}-0.128^{* * *} \\
(-3.075)\end{array}$ & $\begin{array}{c}-0.180^{* *} \\
(-2.574)\end{array}$ & $\begin{array}{l}-0.130^{* * *} \\
(-3.188)\end{array}$ & $\begin{array}{l}-0.130^{* * *} \\
(-5.597)\end{array}$ & $\begin{array}{l}-0.153^{* * *} \\
(-5.039)\end{array}$ & $\begin{array}{l}-0.139^{* * *} \\
(-3.307)\end{array}$ \\
\hline External Gov. Debt $t_{t-1}$ & $\begin{array}{c}0.017 \\
(0.418)\end{array}$ & $\begin{array}{c}-0.009 \\
(-0.184)\end{array}$ & $\begin{array}{c}0.042 \\
(0.965)\end{array}$ & $\begin{array}{c}0.010 \\
(0.321)\end{array}$ & $\begin{array}{c}-0.010 \\
(-0.227)\end{array}$ & $\begin{array}{c}0.000 \\
(0.007)\end{array}$ \\
\hline Ln(GDP Per Capita $\left.{ }_{t-1}\right)$ & $\begin{array}{c}0.027 \\
(1.349)\end{array}$ & $\begin{array}{c}0.065^{* *} \\
(2.677)\end{array}$ & $\begin{array}{c}0.038 \\
(1.187)\end{array}$ & $\begin{array}{c}0.034^{* *} \\
(2.525)\end{array}$ & $\begin{array}{c}0.042^{* *} \\
(2.494)\end{array}$ & $\begin{array}{c}0.037 \\
(1.430)\end{array}$ \\
\hline $\operatorname{Ln}($ CPI Index Level $t-1)$ & $\begin{array}{c}0.022 \\
(0.533)\end{array}$ & $\begin{array}{c}0.013 \\
(0.239)\end{array}$ & $\begin{array}{c}-0.043 \\
(-0.705)\end{array}$ & $\begin{array}{c}-0.015 \\
(-0.391)\end{array}$ & $\begin{array}{c}0.022 \\
(0.440)\end{array}$ & $\begin{array}{c}-0.047 \\
(-0.582)\end{array}$ \\
\hline $\operatorname{Ln}\left(\mathrm{S} \& \mathrm{P}\right.$ Index Level $\left._{t-1}\right)$ & $\begin{array}{c}-0.015 \\
(-1.163)\end{array}$ & $\begin{array}{c}-0.036^{* *} \\
(-2.093)\end{array}$ & $\begin{array}{l}-0.045^{* * *} \\
(-2.964)\end{array}$ & $\begin{array}{c}-0.005 \\
(-0.826)\end{array}$ & $\begin{array}{c}-0.004 \\
(-0.451)\end{array}$ & $\begin{array}{c}-0.014 \\
(-1.493)\end{array}$ \\
\hline Ln(Exchange Rate $\left.{ }_{t-1}\right)$ & $\begin{array}{c}-0.004 \\
(-1.414)\end{array}$ & $\begin{array}{c}-0.001 \\
(-0.091)\end{array}$ & $\begin{array}{c}-0.003 \\
(-1.512)\end{array}$ & $\begin{array}{c}-0.000 \\
(-0.064)\end{array}$ & $\begin{array}{c}0.001 \\
(0.307)\end{array}$ & $\begin{array}{c}-0.001 \\
(-0.323)\end{array}$ \\
\hline Unemployment Rate $_{t-1}$ & $\begin{array}{c}0.222 \\
(1.638)\end{array}$ & $\begin{array}{c}0.312 \\
(1.664)\end{array}$ & $\begin{array}{c}0.025 \\
(0.141)\end{array}$ & $\begin{array}{c}-0.038 \\
(-0.434)\end{array}$ & $\begin{array}{c}-0.070 \\
(-0.590)\end{array}$ & $\begin{array}{c}0.005 \\
(0.033)\end{array}$ \\
\hline Tangibility $_{t-1}$ & $\begin{array}{c}0.087 \\
(1.245)\end{array}$ & $\begin{array}{c}-0.026 \\
(-0.248)\end{array}$ & $\begin{array}{c}0.182^{* *} \\
(2.049)\end{array}$ & $\begin{array}{c}0.001 \\
(0.024)\end{array}$ & $\begin{array}{c}-0.062 \\
(-0.893)\end{array}$ & $\begin{array}{c}0.005 \\
(0.070)\end{array}$ \\
\hline $\operatorname{Ln}\left(\right.$ Assets $\left._{t-1}\right)$ & $\begin{array}{l}0.000 \\
(0.034)\end{array}$ & $\begin{array}{c}0.011 \\
(1.129)\end{array}$ & $\begin{array}{c}-0.007 \\
(-1.029)\end{array}$ & $\begin{array}{c}0.000 \\
(0.006)\end{array}$ & $\begin{array}{c}0.009 \\
(0.801)\end{array}$ & $\begin{array}{c}0.016^{*} \\
(1.920)\end{array}$ \\
\hline $\mathrm{ROA}_{t-1}$ & $\begin{array}{l}-0.690^{* * *} \\
(-5.141)\end{array}$ & $\begin{array}{l}-0.980^{* * *} \\
(-5.004)\end{array}$ & $\begin{array}{l}-1.033^{* * *} \\
(-4.223)\end{array}$ & $\begin{array}{c}-0.063 \\
(-0.863)\end{array}$ & $\begin{array}{c}-0.107 \\
(-1.025)\end{array}$ & $\begin{array}{c}-0.091 \\
(-0.665)\end{array}$ \\
\hline Market-to-Book ${ }_{t-1}$ & $\begin{array}{c}0.001 \\
(1.608)\end{array}$ & $\begin{array}{c}0.003^{* * *} \\
(2.713)\end{array}$ & $\begin{array}{l}-0.006^{* *} \\
(-2.276)\end{array}$ & $\begin{array}{c}-0.001 \\
(-1.123)\end{array}$ & $\begin{array}{c}-0.000 \\
(-0.459)\end{array}$ & $\begin{array}{c}-0.004 \\
(-1.204)\end{array}$ \\
\hline Observations & 671 & 671 & 671 & 630 & 630 & 630 \\
\hline Adj. R-squared & 0.723 & 0.772 & 0.732 & 0.197 & 0.199 & 0.416 \\
\hline Year FE & YES & YES & YES & YES & YES & YES \\
\hline Country FE & YES & YES & YES & NO & NO & NO \\
\hline
\end{tabular}




\section{Table 6: Constant Elasticity Specification (Country Panel)}

Corporate Debt is calculated by summing the dollar values of debt over all firms in a country and year. Ln(Government Debt) is the natural logarithm of the dollar value of government debt outstanding. Standard errors are clustered at the country level. Statistical significance at the 10\%, 5\% and $1 \%$ levels are denoted by "**, "***" and “***", respectively.

\begin{tabular}{|c|c|c|}
\hline & Panel A: Fixed Effects & Panel B: First Differences \\
\hline & Ln(Corp. Debt) & $\operatorname{Ln}($ Corp. Debt $)$ \\
\hline $\operatorname{Ln}\left(\right.$ Gov. Debt $\left.{ }_{t-1}\right)$ & $\begin{array}{c}-0.145^{* *} \\
(-2.297)\end{array}$ & $\begin{array}{l}-0.198^{* * *} \\
(-2.924)\end{array}$ \\
\hline Ln(GDP Per Capita Cat $\left._{t}\right)$ & $\begin{array}{c}0.151^{*} \\
(1.702)\end{array}$ & $\begin{array}{c}-0.042 \\
(-0.360)\end{array}$ \\
\hline Ln(CPI Index Level $\left.{ }_{t-1}\right)$ & $\begin{array}{c}0.112 \\
(1.073)\end{array}$ & $\begin{array}{c}0.237 \\
(0.696)\end{array}$ \\
\hline $\operatorname{Ln}(\mathrm{S} \& \mathrm{P}$ Index Level $t-1)$ & $\begin{array}{c}0.034 \\
(0.794)\end{array}$ & $\begin{array}{l}0.161^{* * *} \\
(3.818)\end{array}$ \\
\hline Ln(Exchange Rate E $\left._{t-1}\right)$ & $\begin{array}{l}-0.041^{* * *} \\
(-2.902)\end{array}$ & $\begin{array}{c}0.025 \\
(1.440)\end{array}$ \\
\hline Unemployment Rate $_{t-1}$ & $\begin{array}{l}1.134^{* * *} \\
(2.831)\end{array}$ & $\begin{array}{c}-0.529 \\
(-0.634)\end{array}$ \\
\hline Tangibility $_{t-1}$ & $\begin{array}{c}0.097 \\
(0.350)\end{array}$ & $\begin{array}{c}0.181 \\
(0.484)\end{array}$ \\
\hline $\operatorname{Ln}\left(\right.$ Assets $\left._{t-1}\right)$ & $\begin{array}{c}1.006^{* * *} \\
(25.759)\end{array}$ & $\begin{array}{c}0.896^{* * *} \\
(11.848)\end{array}$ \\
\hline $\mathrm{ROA}_{t-1}$ & $\begin{array}{l}-2.025^{* * *} \\
(-3.978)\end{array}$ & $\begin{array}{c}0.506 \\
(1.215)\end{array}$ \\
\hline Market-to-Book $_{t-1}$ & $\begin{array}{c}0.002 \\
(0.720)\end{array}$ & $\begin{array}{c}0.002 \\
(0.441)\end{array}$ \\
\hline Observations & 813 & 779 \\
\hline Adj. R-squared & 0.990 & 0.681 \\
\hline Year FE & YES & YES \\
\hline Country FE & YES & NO \\
\hline
\end{tabular}




\section{Table 7: Baseline Specification (Firm Panel)}

Panels A and B report the estimation results from firm-fixed effects and first differences regressions. All regressions include year-fixed effects. Standard errors are clustered at the country level. Statistical significance at the $10 \%, 5 \%$ and $1 \%$ levels are denoted by "**, " **" and "***", respectively.

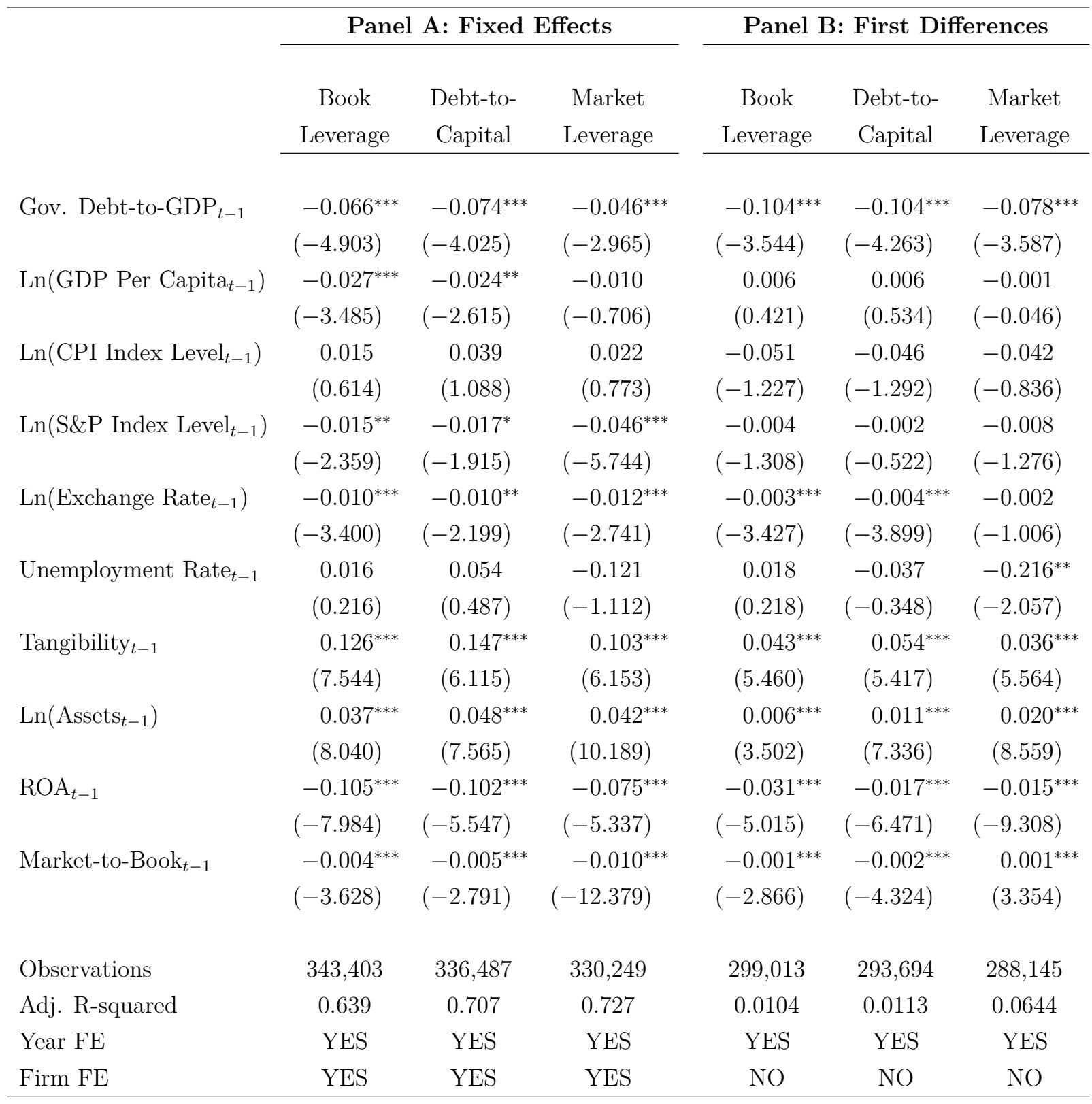




\section{Table 8: Firm Characteristics and Crowding Out}

This table reports the results from firm-fixed effects regressions with firm size and profitability interactions. Large equals one if a firm's lagged book assets is in the top 20 percentile of its country distribution and zero otherwise. Profitable indicates whether a firm's lagged ROA is above its country median in a given year. All regressions include firm- and year-fixed effects. Standard errors are clustered at the country level. Statistical significance at the $10 \%, 5 \%$ and $1 \%$ levels are denoted by "**, "*** and "***", respectively.

\begin{tabular}{|c|c|c|c|c|c|c|}
\hline & $\begin{array}{c}\text { Book } \\
\text { Leverage }\end{array}$ & $\begin{array}{c}\text { Debt-to- } \\
\text { Capital }\end{array}$ & $\begin{array}{l}\text { Market } \\
\text { Leverage }\end{array}$ & $\begin{array}{c}\text { Book } \\
\text { Leverage }\end{array}$ & $\begin{array}{l}\text { Debt-to- } \\
\text { Capital }\end{array}$ & $\begin{array}{l}\text { Market } \\
\text { Leverage }\end{array}$ \\
\hline Gov. Debt-to-GDP ${ }_{t-1}$ & $\begin{array}{l}-0.063^{* * *} \\
(-4.600)\end{array}$ & $\begin{array}{l}-0.070^{* * *} \\
(-3.784)\end{array}$ & $\begin{array}{l}-0.044^{* * *} \\
(-2.866)\end{array}$ & $\begin{array}{l}-0.060^{* * *} \\
(-4.627)\end{array}$ & $\begin{array}{l}-0.069^{* * *} \\
(-3.861)\end{array}$ & $\begin{array}{l}-0.042^{* * *} \\
(-2.764)\end{array}$ \\
\hline X Large & $\begin{array}{l}-0.012^{* * *} \\
(-2.792)\end{array}$ & $\begin{array}{c}-0.014^{*} \\
(-1.964)\end{array}$ & $\begin{array}{l}-0.010^{* *} \\
(-2.299)\end{array}$ & & & \\
\hline X Profitable & & & & $\begin{array}{l}-0.017^{* * *} \\
(-6.063)\end{array}$ & $\begin{array}{l}-0.021^{* * *} \\
(-6.753)\end{array}$ & $\begin{array}{l}-0.017^{* * *} \\
(-6.488)\end{array}$ \\
\hline Large & $\begin{array}{l}0.016^{* *} \\
(2.695)\end{array}$ & $\begin{array}{c}0.018^{*} \\
(2.002)\end{array}$ & $\begin{array}{l}0.016^{* * *} \\
(2.784)\end{array}$ & & & \\
\hline Profitable & & & & $\begin{array}{c}-0.005 \\
(-1.326)\end{array}$ & $\begin{array}{l}-0.014^{* * *} \\
(-3.172)\end{array}$ & $\begin{array}{l}-0.014^{* * *} \\
(-3.814)\end{array}$ \\
\hline Ln(GDP Per Capita $\left.{ }_{t-1}\right)$ & $\begin{array}{l}-0.028^{* * *} \\
(-3.463)\end{array}$ & $\begin{array}{l}-0.025^{* *} \\
(-2.698)\end{array}$ & $\begin{array}{c}-0.011 \\
(-0.735)\end{array}$ & $\begin{array}{l}-0.027^{* * *} \\
(-3.290)\end{array}$ & $\begin{array}{l}-0.024^{* * *} \\
(-2.741)\end{array}$ & $\begin{array}{c}-0.010 \\
(-0.655)\end{array}$ \\
\hline $\operatorname{Ln}\left(\right.$ CPI Index Level $\left.t_{t-1}\right)$ & $\begin{array}{c}0.015 \\
(0.624)\end{array}$ & $\begin{array}{c}0.039 \\
(1.095)\end{array}$ & $\begin{array}{c}0.023 \\
(0.785)\end{array}$ & $\begin{array}{c}0.014 \\
(0.569)\end{array}$ & $\begin{array}{c}0.037 \\
(1.036)\end{array}$ & $\begin{array}{c}0.021 \\
(0.734)\end{array}$ \\
\hline $\operatorname{Ln}\left(\mathrm{S} \& \mathrm{P}\right.$ Index Level $\left._{t-1}\right)$ & $\begin{array}{c}-0.015^{* *} \\
(-2.325)\end{array}$ & $\begin{array}{c}-0.017^{*} \\
(-1.892)\end{array}$ & $\begin{array}{l}-0.047^{* * *} \\
(-5.648)\end{array}$ & $\begin{array}{l}-0.016^{* *} \\
(-2.401)\end{array}$ & $\begin{array}{c}-0.018^{*} \\
(-1.982)\end{array}$ & $\begin{array}{l}-0.047^{* * *} \\
(-5.688)\end{array}$ \\
\hline $\operatorname{Ln}\left(\right.$ Exchange Rate $\left.{ }_{t-1}\right)$ & $\begin{array}{l}-0.010^{* * *} \\
(-3.392)\end{array}$ & $\begin{array}{l}-0.010^{* *} \\
(-2.196)\end{array}$ & $\begin{array}{l}-0.012^{* * *} \\
(-2.734)\end{array}$ & $\begin{array}{l}-0.010^{* * *} \\
(-3.371)\end{array}$ & $\begin{array}{c}-0.010^{\text {** }} \\
(-2.193)\end{array}$ & $\begin{array}{c}-0.012^{* *} \\
(-2.694)\end{array}$ \\
\hline Unemployment Rate $_{t-1}$ & $\begin{array}{c}0.021 \\
(0.293)\end{array}$ & $\begin{array}{c}0.061 \\
(0.551)\end{array}$ & $\begin{array}{c}-0.115 \\
(-1.067)\end{array}$ & $\begin{array}{c}0.017 \\
(0.229)\end{array}$ & $\begin{array}{c}0.053 \\
(0.480)\end{array}$ & $\begin{array}{c}-0.123 \\
(-1.090)\end{array}$ \\
\hline Tangibility $_{t-1}$ & $\begin{array}{l}0.126^{* * *} \\
(7.559)\end{array}$ & $\begin{array}{l}0.147^{* * *} \\
(6.128)\end{array}$ & $\begin{array}{c}0.103^{* * *} \\
(6.182)\end{array}$ & $\begin{array}{l}0.126^{* * *} \\
(7.466)\end{array}$ & $\begin{array}{l}0.148^{* * *} \\
(6.028)\end{array}$ & $\begin{array}{c}0.104^{* * *} \\
(6.176)\end{array}$ \\
\hline $\operatorname{Ln}\left(\right.$ Assets $\left._{t-1}\right)$ & $\begin{array}{l}0.036^{* * *} \\
(7.806)\end{array}$ & $\begin{array}{l}0.047^{* * *} \\
(7.460)\end{array}$ & $\begin{array}{l}0.041^{* * *} \\
(9.814)\end{array}$ & $\begin{array}{c}0.037^{* * *} \\
(8.025)\end{array}$ & $\begin{array}{c}0.048^{* * *} \\
(7.517)\end{array}$ & $\begin{array}{c}0.042^{* * *} \\
(10.308)\end{array}$ \\
\hline $\mathrm{ROA}_{t-1}$ & $\begin{array}{l}-0.104^{* * *} \\
(-7.864)\end{array}$ & $\begin{array}{l}-0.101^{* * *} \\
(-5.485)\end{array}$ & $\begin{array}{l}-0.074^{* * *} \\
(-5.275)\end{array}$ & $\begin{array}{l}-0.093^{* * *} \\
(-9.152)\end{array}$ & $\begin{array}{l}-0.080^{* * *} \\
(-5.723)\end{array}$ & $\begin{array}{l}-0.055^{* * *} \\
(-5.563)\end{array}$ \\
\hline Market-to-Book ${ }_{t-1}$ & $\begin{array}{c}-0.004^{* * *} \\
(-3.685)\end{array}$ & $\begin{array}{l}-0.005^{* * *} \\
(-2.825)\end{array}$ & $\begin{array}{c}-0.010^{* * *} \\
(-12.711)\end{array}$ & $\begin{array}{l}-0.003^{* * *} \\
(-2.864)\end{array}$ & $\begin{array}{c}-0.004^{* *} \\
(-2.223)\end{array}$ & $\begin{array}{c}-0.009^{* * *} \\
(-12.594)\end{array}$ \\
\hline Observations & 343,403 & 336,487 & 330,249 & 343,403 & 336,487 & 330,249 \\
\hline Adj. R-squared & 0.639 & 0.707 & 0.727 & 0.640 & 0.709 & 0.730 \\
\hline Year FE & YES & YES & YES & YES & YES & YES \\
\hline Firm FE & YES & YES & YES & YES & YES & YES \\
\hline
\end{tabular}




\section{Table 9: Country Characteristics and Crowding Out}

This table reports the results from fixed effects regressions with government debt-to-GDP ratio interacted with proxies for the availability of alternative means of external financing. Each year, we split the sample below and above the median based on lagged Bank Dependence and Market Capitalization. Bank Dependence is measured by total bank credit to private sector as a fraction of GDP. Market Capitalization is total market value of public firms as a percent of GDP. All regressions include the control variables from the baseline specification in Table 4, year- and country-fixed effects as well as the interactions of Bank Dependence and Market Capitalization dummy variables with the control variables (including year-fixed effects) which are not reported to save space. Standard errors are clustered at the country level. Statistical significance at the $10 \%, 5 \%$ and $1 \%$ levels are denoted by "**, "**" and "***", respectively.

\begin{tabular}{|c|c|c|c|c|c|c|}
\hline & $\begin{array}{c}\text { Book } \\
\text { Leverage }\end{array}$ & $\begin{array}{c}\text { Debt-to- } \\
\text { Capital }\end{array}$ & $\begin{array}{c}\text { Market } \\
\text { Leverage }\end{array}$ & $\begin{array}{c}\text { Book } \\
\text { Leverage }\end{array}$ & $\begin{array}{l}\text { Debt-to- } \\
\text { Capital }\end{array}$ & $\begin{array}{c}\text { Market } \\
\text { Leverage }\end{array}$ \\
\hline Gov. Debt-to-GDP ${ }_{t-1}$ & $\begin{array}{l}-0.110^{* * *} \\
(-5.719)\end{array}$ & $\begin{array}{l}-0.150^{* * *} \\
(-3.509)\end{array}$ & $\begin{array}{l}-0.085^{* * *} \\
(-3.870)\end{array}$ & $\begin{array}{l}-0.098^{* * *} \\
(-4.668)\end{array}$ & $\begin{array}{l}-0.143^{* * *} \\
(-4.008)\end{array}$ & $\begin{array}{l}-0.073^{* * *} \\
(-3.187)\end{array}$ \\
\hline X High Bank Dependence $e_{t-1}$ & $\begin{array}{c}0.073^{* *} \\
(2.141)\end{array}$ & $\begin{array}{c}0.091^{* *} \\
(2.092)\end{array}$ & $\begin{array}{c}0.064^{*} \\
(1.920)\end{array}$ & & & \\
\hline X Low Market Capitalization $_{t-1}$ & & & & $\begin{array}{c}0.031^{*} \\
(1.746)\end{array}$ & $\begin{array}{l}0.052^{* *} \\
(2.124)\end{array}$ & $\begin{array}{c}0.024 \\
(1.296)\end{array}$ \\
\hline High Bank Dependence ${ }_{t-1}$ & $\begin{array}{c}-0.189 \\
(-0.924)\end{array}$ & $\begin{array}{c}-0.140 \\
(-0.471)\end{array}$ & $\begin{array}{c}0.047 \\
(0.211)\end{array}$ & & & \\
\hline Low Market Capitalization $_{t-1}$ & & & & $\begin{array}{c}0.089 \\
(0.932)\end{array}$ & $\begin{array}{c}0.134 \\
(0.999)\end{array}$ & $\begin{array}{c}0.010 \\
(0.079)\end{array}$ \\
\hline Observations & 761 & 761 & 761 & 767 & 767 & 767 \\
\hline Adj. R-squared & 0.713 & 0.759 & 0.731 & 0.714 & 0.769 & 0.739 \\
\hline Control variables & YES & YES & YES & YES & YES & YES \\
\hline Year FE & YES & YES & YES & YES & YES & YES \\
\hline Country FE & YES & YES & YES & YES & YES & YES \\
\hline Interactions with controls & YES & YES & YES & YES & YES & YES \\
\hline Interactions with year FE & YES & YES & YES & YES & YES & YES \\
\hline
\end{tabular}




\section{Table 10: Instrumental Variable Specification}

This table reports the first and second stage estimation results from instrumental variables regressions where Gov. Debt-to-GDP (Panel A) and Domestic Government Debt-to-GDP (Panel B) are instrumented by lagged Military Expenditures-to-GDP. We drop firms in industries that are defense dependent. All regressions include year- and country-fixed effects. Standard errors are clustered at the country level. Statistical significance at the $10 \%, 5 \%$ and $1 \%$ levels are denoted by "**, "**" and "***", respectively.

Panel A: Total Government Debt

\begin{tabular}{|c|c|c|c|}
\hline First Stage & \multicolumn{3}{|c|}{ Second Stage } \\
\hline & Book & Debt-to- & Market \\
\hline Gov. Debt-to-GDP ${ }_{t-1}$ & Leverage $_{t}$ & Capital $_{t}$ & Leverage $_{t}$ \\
\hline
\end{tabular}

Military Expenditures-to-GDP $\mathrm{G}_{t-2}$

$11.923^{* *}$

(2.116)

Gov. Debt-to-GDP ${ }_{t-1}$

Ln(GDP Per Capita Can $_{t-1}$ )

$-0.210^{* * *}$

$(-2.851)$

Ln(CPI Index Level $\left.{ }_{t-1}\right)$

Ln(S\&P Index Level $\left._{t-1}\right)$

Unemployment Rate $_{t-1}$

Ln(Exchange Rate $\left._{t-1}\right)$

Tangibility $_{t-1}$

$\operatorname{Ln}\left(\right.$ Assets $\left._{t-1}\right)$

$\mathrm{ROA}_{t-1}$

Market-to-Book ${ }_{t-1}$

Underidentification test:

Kleibergen-Paap rk LM

$\mathrm{P}$-value

Weak identification test:

Kleibergen-Paap Wald rk F

Observations

Adj. R-squared

Year FE

Country FE
0.032

$-0.260^{*}$

$(-2.821)$

$2.445^{* * *}$

(3.627)

0.009

(0.703)

0.089

(0.354)

0.024

(0.843)

0.115

(0.242)

$-0.003$

$(-0.716)$

4.48

800

YES

YES

$\begin{array}{ccc}-0.142^{* *} & -0.174^{*} & -0.188^{* *} \\ (-2.140) & (-1.934) & (-2.034) \\ 0.001 & 0.036 & -0.001 \\ (0.047) & (1.281) & (-0.029) \\ -0.004 & 0.007 & -0.057 \\ (-0.108) & (0.156) & (-1.306) \\ -0.024^{*} & -0.040^{* *} & -0.062^{* * *} \\ (-1.706) & (-2.042) & (-3.957) \\ 0.436^{* *} & 0.540^{* *} & 0.508^{*} \\ (2.321) & (2.105) & (1.777) \\ -0.014 * * * & -0.014^{* *} & -0.012^{* * *} \\ (-3.189) & (-1.962) & (-2.850) \\ 0.051 & -0.054 & 0.158^{*} \\ (0.681) & (-0.543) & (1.830) \\ -0.001 & 0.006 & -0.007 \\ (-0.080) & (0.604) & (-0.777) \\ -0.802^{* * *} & -1.112^{* * *} & -1.011^{* * *} \\ (-5.231) & (-5.324) & (-3.750) \\ -0.000 & 0.003^{* *} & -0.008^{* * *} \\ (-0.237) & (2.351) & (-3.955)\end{array}$

$\begin{array}{ccc}800 & 800 & 800 \\ 0.660 & 0.721 & 0.652 \\ \text { YES } & \text { YES } & \text { YES } \\ \text { YES } & \text { YES } & \text { YES }\end{array}$




\section{Instrumental Variables (Cont.)}

Panel B: Domestic Government Debt

\begin{tabular}{|c|c|c|c|c|}
\hline & \multirow{2}{*}{$\begin{array}{c}\text { First Stage } \\
\text { Gov. Debt-to-GDP }{ }_{t-2}\end{array}$} & \multicolumn{3}{|c|}{ Second Stage } \\
\hline & & $\begin{array}{c}\text { Book } \\
\text { Leverage }_{t}\end{array}$ & $\begin{array}{l}\text { Debt-to- } \\
\text { Capital }_{t}\end{array}$ & $\begin{array}{c}\text { Market } \\
\text { Leverage }_{t}\end{array}$ \\
\hline Military Expenditures-to-GDP ${ }_{t-1}$ & $\begin{array}{c}6.401^{* * *} \\
(3.293)\end{array}$ & & & \\
\hline Domestic Gov. Debt $t_{t-1}$ & & $\begin{array}{l}-0.295^{* *} \\
(-2.219)\end{array}$ & $\begin{array}{c}-0.464^{* * *} \\
(-2.721)\end{array}$ & $\begin{array}{l}-0.345^{* *} \\
(-2.206)\end{array}$ \\
\hline Ln(GDP Per Capita C $\left._{t-1}\right)$ & $\begin{array}{c}0.003 \\
(0.059)\end{array}$ & $\begin{array}{c}0.027 \\
(1.251)\end{array}$ & $\begin{array}{c}0.069^{* * *} \\
(2.764)\end{array}$ & $\begin{array}{c}0.031 \\
(0.963)\end{array}$ \\
\hline Ln(CPI Index Level $\left.{ }_{t-1}\right)$ & $\begin{array}{l}-0.219^{* *} \\
(-2.260)\end{array}$ & $\begin{array}{l}-0.020 \\
(-0.333)\end{array}$ & $\begin{array}{l}-0.052 \\
(-0.656)\end{array}$ & $\begin{array}{l}-0.092 \\
(-1.375)\end{array}$ \\
\hline Ln(S\&P Index Level L $\left._{t-1}\right)$ & $\begin{array}{l}-0.031 \\
(-1.275)\end{array}$ & $\begin{array}{l}-0.020 \\
(-1.499)\end{array}$ & $\begin{array}{l}-0.042^{* *} \\
(-2.276)\end{array}$ & $\begin{array}{c}-0.050 * * * \\
(-3.203)\end{array}$ \\
\hline 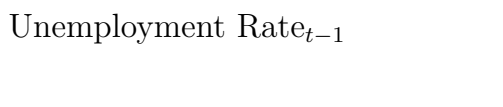 & $\begin{array}{c}1.139 * * * \\
(3.897)\end{array}$ & $\begin{array}{l}0.451^{* *} \\
(2.400)\end{array}$ & $\begin{array}{l}0.669^{* *} \\
(2.493)\end{array}$ & $\begin{array}{c}0.398 \\
(1.637)\end{array}$ \\
\hline Ln(Exchange Rate Ra-1 $\left._{t}\right)$ & $\begin{array}{c}0.046^{* * *} \\
(4.365)\end{array}$ & $\begin{array}{c}0.003 \\
(0.393)\end{array}$ & $\begin{array}{c}0.012 \\
(1.165)\end{array}$ & $\begin{array}{c}0.005 \\
(0.564)\end{array}$ \\
\hline Tangibility $_{t-1}$ & $\begin{array}{l}-0.142 \\
(-0.815)\end{array}$ & $\begin{array}{c}0.066 \\
(0.885)\end{array}$ & $\begin{array}{l}-0.065 \\
(-0.569)\end{array}$ & $\begin{array}{l}0.163^{*} \\
(1.739)\end{array}$ \\
\hline $\operatorname{Ln}\left(\right.$ Assets $\left._{t-1}\right)$ & $\begin{array}{l}0.045^{*} \\
(1.959)\end{array}$ & $\begin{array}{c}0.007 \\
(0.634)\end{array}$ & $\begin{array}{l}0.023^{*} \\
(1.883)\end{array}$ & $\begin{array}{c}0.003 \\
(0.337)\end{array}$ \\
\hline $\mathrm{ROA}_{t-1}$ & $\begin{array}{l}0.478^{*} \\
(1.859)\end{array}$ & $\begin{array}{c}-0.631^{* * *} \\
(-4.039)\end{array}$ & $\begin{array}{c}-0.792^{* * *} \\
(-3.890)\end{array}$ & $\begin{array}{c}-0.937^{* * *} \\
(-3.628)\end{array}$ \\
\hline Market-to-Book ${ }_{t-1}$ & $\begin{array}{c}-0.004^{* *} \\
(-2.571)\end{array}$ & $\begin{array}{c}0.001 \\
(0.658)\end{array}$ & $\begin{array}{l}0.002^{*} \\
(1.790)\end{array}$ & $\begin{array}{c}-0.006 * * * \\
(-2.672)\end{array}$ \\
\hline Underidentification tests: & & & & \\
\hline Kleibergen-Paap rk LM & 7.28 & & & \\
\hline $\begin{array}{l}\text { P-value } \\
\text { Weak identification tests: }\end{array}$ & 0.007 & & & \\
\hline Kleibergen-Paap Wald rk F & 10.84 & & & \\
\hline Observations & 659 & 659 & 659 & 659 \\
\hline Adj. R-squared & & 0.672 & 0.702 & 0.668 \\
\hline Year FE & YES & YES & YES & YES \\
\hline Country FE & YES & YES & YES & YES \\
\hline
\end{tabular}




\section{Table 11: EMU Integration}

This table analyzes the impact of the EMU integration on the sensitivity of corporate leverage to government debt. Panels A and B report the results from fixed effects and first differences regressions, respectively. $E M U$ is a variable that indicates whether the country is a member of the European Monetary Union. After 1998 is an indicator for the period between 1999 and 2006. All regressions include macroeconomic and firm-level controls as well as their interactions with EMU, After 1998, and EMU X After 1998. Sample period is from 1990 to 2006. Standard errors are clustered at the country level. Statistical significance at the $10 \%, 5 \%$ and $1 \%$ levels are denoted by "**, "**" and "***", respectively.

\begin{tabular}{|c|c|c|c|c|c|c|}
\hline & \multicolumn{3}{|c|}{ Panel A: Fixed Effects } & \multicolumn{3}{|c|}{ Panel B: First Differences } \\
\hline & $\begin{array}{c}\text { Book } \\
\text { Leverage }\end{array}$ & $\begin{array}{l}\text { Debt-to- } \\
\text { Capital }\end{array}$ & $\begin{array}{l}\text { Market } \\
\text { Leverage }\end{array}$ & $\begin{array}{c}\text { Book } \\
\text { Leverage }\end{array}$ & $\begin{array}{l}\text { Debt-to- } \\
\text { Capital }\end{array}$ & $\begin{array}{l}\text { Market } \\
\text { Leverage }\end{array}$ \\
\hline Gov. Debt-to-GDP ${ }_{t-1}$ & $\begin{array}{l}-0.147^{* * *} \\
(-4.450)\end{array}$ & $\begin{array}{l}-0.203^{* * *} \\
(-4.256)\end{array}$ & $\begin{array}{l}-0.140^{* * *} \\
(-3.703)\end{array}$ & $\begin{array}{l}-0.147^{* * *} \\
(-3.543)\end{array}$ & $\begin{array}{l}-0.315^{* * *} \\
(-4.176)\end{array}$ & $\begin{array}{l}-0.166^{* *} \\
(-2.708)\end{array}$ \\
\hline $\mathrm{X}$ EMU & $\begin{array}{c}0.069 \\
(1.070)\end{array}$ & $\begin{array}{c}0.032 \\
(0.302)\end{array}$ & $\begin{array}{c}0.081 \\
(1.504)\end{array}$ & $\begin{array}{c}-0.062 \\
(-1.091)\end{array}$ & $\begin{array}{c}0.085 \\
(0.726)\end{array}$ & $\begin{array}{c}0.026 \\
(0.198)\end{array}$ \\
\hline X After 1998 & $\begin{array}{l}0.010 \\
(0.441)\end{array}$ & $\begin{array}{c}0.039 \\
(1.115)\end{array}$ & $\begin{array}{c}-0.009 \\
(-0.378)\end{array}$ & $\begin{array}{c}0.022 \\
(0.262)\end{array}$ & $\begin{array}{c}0.176 \\
(1.381)\end{array}$ & $\begin{array}{c}-0.128 \\
(-1.245)\end{array}$ \\
\hline X After 1998 X EMU & $\begin{array}{l}0.116^{* *} \\
(2.599)\end{array}$ & $\begin{array}{c}0.087 \\
(1.067)\end{array}$ & $\begin{array}{l}0.151^{* * *} \\
(3.749)\end{array}$ & $\begin{array}{l}0.313^{* *} \\
(2.223)\end{array}$ & $\begin{array}{c}0.074 \\
(0.376)\end{array}$ & $\begin{array}{r}0.382^{*} \\
(1.833)\end{array}$ \\
\hline Observations & 498 & 498 & 498 & 465 & 465 & 465 \\
\hline Adj. R-squared & 0.831 & 0.822 & 0.814 & 0.143 & 0.155 & 0.230 \\
\hline Control Variables & YES & YES & YES & YES & YES & YES \\
\hline EMU Interactions & YES & YES & YES & YES & YES & YES \\
\hline $\begin{array}{l}\text { After } 1998 \text { Interactions } \\
\text { After } 1998 \text { X }\end{array}$ & YES & YES & YES & YES & YES & YES \\
\hline EMU Interactions & YES & YES & YES & YES & YES & YES \\
\hline Country FE & YES & YES & YES & NO & NO & NO \\
\hline
\end{tabular}




\section{Appendix}

\section{A.1 Equilibrium Leverage and Financing Costs}

The following equation summarizes the relation between the equity premium and the leverage ratio in equilibrium:

$$
\theta\left(d^{*}-\lambda\right)=\rho v^{\prime}\left(\rho d^{*}\left(1-w_{G}\right)+w_{G}\right)
$$

Notice that in equilibrium, the leverage ratio is above the firm's target debt level. Hypothetically, assume the opposite such that $d^{*}<\lambda$. Given our assumption that $v^{\prime}($.$) is a$ decreasing function and $v^{\prime}(1)=0$, this implies $\rho d^{*}\left(1-w_{G}\right)+w_{G}>1$ or $\rho d^{*}>1$. Since $\rho \leq 1$, this generates a contradiction such that $d^{*}>1$.

Taking the derivative of both sides of equation (8) with respect to $\theta$ yields

$$
\frac{\partial d^{*}}{\partial \theta}=\frac{d^{*}-\lambda}{\rho^{2}\left(1-w_{G}\right) v^{\prime \prime}\left(\rho d^{*}\left(1-w_{G}\right)+w_{G}\right)-\theta} \leq 0,
$$

which suggests that higher financing frictions are associated with lower leverage ratios in equilibrium. Given that $d^{*} \geq \lambda$, the negative sign for the derivative implies that firms with higher financing costs have equilibrium leverage ratios that are closer to the target.

\section{A.2 Proof of Proposition 1}

We take the derivative of both sides in equation (8) with respect to $w_{G}$ to obtain the following expression

$$
\frac{\partial d^{*}}{\partial w_{G}}=\frac{\rho\left(1-\rho d^{*}\right) v^{\prime \prime}\left(\rho d^{*}\left(1-w_{G}\right)+w_{G}\right)}{\theta-\rho^{2}\left(1-w_{G}\right) v^{\prime \prime}\left(\rho d^{*}\left(1-w_{G}\right)+w_{G}\right)} \leq 0 .
$$

Given that $v^{\prime \prime}() \leq$.0 and $\rho d^{*} \leq 1$, equation (10) implies a negative partial derivative of leverage with respect to government debt.

Conversely, suppose that $\rho d^{*}>1$ holds which implies $\rho d^{*}\left(1-w_{G}\right)+w_{G}>1$. The 
lower bound for $v^{\prime}$ is chosen such that households don't obtain additional utility from holding more debt if all their wealth is already invested in government debt securities (i.e. $\left.v^{\prime}(1)=0\right)$. Therefore in equilibrium, $\rho v^{\prime}\left(\rho d^{*}\left(1-w_{G}\right)+w_{G}\right)<0$ which implies that $d^{*}<\lambda$. Given that $\lambda<1$ and $\rho \leq 1, d^{*}<\lambda$ and $d^{*}>1$ cannot be satisfied simultaneously. Hence, $\rho d^{*} \leq 1$ must hold in equilibrium.

Using equation (4), one can show that

$$
\frac{\partial w_{D}^{*}}{\partial w_{G}}=\frac{\partial d^{*}}{\partial w_{G}}\left(1-w_{G}\right)-d^{*} \leq 0
$$

Thus, as government debt increases, both $d^{*}$ and $w_{D}^{*}$ decrease relative to the previous equilibrium. Similarly, one can also show that the equity premium decreases with government debt as well

$$
\frac{\partial \mu^{*}}{\partial w_{G}}=\theta \frac{\partial d^{*}}{\partial w_{G}} \leq 0
$$




\section{Table A1: Variable Definitions}

This table details the variable construction for the analysis of the sample. Panel A lists the definitions of Compustat variables. The variable Xpressfeed pneumonics are given in italics. The country-level variables follow firm-level definitions and are calculated by aggregating the numerator and denominator values over all firms in a given year and country. Panel B lists the data source for and the definitions of macro variables. If a variable is available through two different sources for a country, we use the data source that provides us with the longest series.

\section{Panel A: Compustat Variables}

Variable

$\operatorname{Ln}($ Assets)

ROA

Tangibility

Market Value of Equity

Market Value of Assets

Market-to-Book

Total Debt

Book Leverage

Debt-to-Capital

Market Leverage
Definition and Compustat Item Name

$\operatorname{Ln}($ Total Book Assets $)=\operatorname{Ln}($ at $)$

Operating Income (Before Depreciation) / Assets = oibdp / at

Net PPE / Assets = ppent / at

$\mathrm{MVE}=\operatorname{prcc} \times$ cshoc

$\mathrm{MVA}=$ at - ceq + MVE

MVA / Total Book Assets

Short-Term Debt + Long-Term Debt $=$ dltt + dlc

Total Debt $/$ Total Book Assets $=(\mathbf{d l t t}+\mathbf{d l c}) /$ at

Total Debt $/$ Total Capital $=(\mathbf{d l t t}+\mathbf{d l c}) /(\mathbf{c e q}+$ dltt + dlc $)$

Total Debt / MVA

\section{Panel B: Macro Variables}

\begin{tabular}{|c|c|c|}
\hline Variable & Data Source & Definition \\
\hline Gov. Debt-to-GDP & WEO data on IMF & Gross government debt (\%GDP) \\
\hline GDP Per Capita & World Bank & GDP per capita (current US\$) \\
\hline Inflation & World Bank and IMF & Inflation, consumer prices (annual \%) \\
\hline S\&P Return & World Bank & S\&P global equity indices (annual \% change) \\
\hline Unemployment Rate & World Bank and IMF & Unemployment, total (\% of total labor force) \\
\hline Nominal Exchange Rate & World Bank and ECB & Official exchange rate (LCU per US\$, period avr.) \\
\hline External Government Debt & IMF, World Bank and ECB & Gross external debt (\%GDP) \\
\hline Bank credit to private sector & BIS & Bank credit (\% GDP) \\
\hline
\end{tabular}




\section{Table A2: Subsample Analysis - OECD Countries (Country Panel)}

This table reports the fixed effects and first differences estimation results for the baseline specification using the panel of OECD countries. All regressions include year-fixed effects. Standard errors are clustered at the country level. Statistical significance at the $10 \%, 5 \%$ and $1 \%$ levels are denoted by "**, "*** and "****, respectively.

\begin{tabular}{|c|c|c|c|c|c|c|}
\hline & \multicolumn{3}{|c|}{ Panel A: Fixed Effects } & \multicolumn{3}{|c|}{ Panel B: First Differences } \\
\hline & $\begin{array}{c}\text { Book } \\
\text { Leverage }\end{array}$ & $\begin{array}{c}\text { Debt-to- } \\
\text { Capital }\end{array}$ & $\begin{array}{c}\text { Market } \\
\text { Leverage }\end{array}$ & $\begin{array}{c}\text { Book } \\
\text { Leverage }\end{array}$ & $\begin{array}{c}\text { Debt-to- } \\
\text { Capital }\end{array}$ & $\begin{array}{c}\text { Market } \\
\text { Leverage }\end{array}$ \\
\hline Gov. Debt-to-GDP ${ }_{t-1}$ & $\begin{array}{l}-0.079^{* * *} \\
(-3.270)\end{array}$ & $\begin{array}{l}-0.098^{* *} \\
(-2.445)\end{array}$ & $\begin{array}{c}-0.048^{*} \\
(-1.997)\end{array}$ & $\begin{array}{l}-0.064^{* *} \\
(-2.683)\end{array}$ & $\begin{array}{l}-0.083^{* *} \\
(-2.458)\end{array}$ & $\begin{array}{c}-0.026 \\
(-0.920)\end{array}$ \\
\hline Ln(GDP Per Capitat $\left.{ }_{t-1}\right)$ & $\begin{array}{c}-0.028 \\
(-0.898)\end{array}$ & $\begin{array}{c}0.020 \\
(0.532)\end{array}$ & $\begin{array}{c}0.020 \\
(0.540)\end{array}$ & $\begin{array}{c}0.062^{* * *} \\
(4.014)\end{array}$ & $\begin{array}{c}0.097^{* * *} \\
(4.383)\end{array}$ & $\begin{array}{c}0.082^{* * *} \\
(4.734)\end{array}$ \\
\hline $\operatorname{Ln}\left(\right.$ CPI Index Level $\left.t_{t-1}\right)$ & $\begin{array}{c}0.032 \\
(0.992)\end{array}$ & $\begin{array}{c}0.064 \\
(1.074)\end{array}$ & $\begin{array}{c}0.002 \\
(0.051)\end{array}$ & $\begin{array}{c}-0.066 \\
(-1.514)\end{array}$ & $\begin{array}{c}-0.083 \\
(-0.971)\end{array}$ & $\begin{array}{c}-0.036 \\
(-0.527)\end{array}$ \\
\hline $\operatorname{Ln}(\mathrm{S} \& \mathrm{P}$ Index Level $t-1)$ & $\begin{array}{c}-0.024 \\
(-1.331)\end{array}$ & $\begin{array}{c}-0.044^{*} \\
(-1.936)\end{array}$ & $\begin{array}{c}-0.049^{* *} \\
(-2.429)\end{array}$ & $\begin{array}{c}-0.003 \\
(-0.352)\end{array}$ & $\begin{array}{c}-0.003 \\
(-0.295)\end{array}$ & $\begin{array}{c}0.001 \\
(0.145)\end{array}$ \\
\hline Unemployment Rate $_{t-1}$ & $\begin{array}{c}0.128 \\
(1.088)\end{array}$ & $\begin{array}{c}0.200 \\
(1.150)\end{array}$ & $\begin{array}{c}0.140^{*} \\
(1.796)\end{array}$ & $\begin{array}{c}-0.048 \\
(-0.598)\end{array}$ & $\begin{array}{c}-0.057 \\
(-0.425)\end{array}$ & $\begin{array}{c}-0.044 \\
(-0.402)\end{array}$ \\
\hline Ln(Exchange Rate Re- $\left._{t-1}\right)$ & $\begin{array}{l}-0.012^{* * *} \\
(-3.269)\end{array}$ & $\begin{array}{c}-0.012^{*} \\
(-1.795)\end{array}$ & $\begin{array}{l}-0.008^{* * *} \\
(-2.843)\end{array}$ & $\begin{array}{c}-0.001 \\
(-0.611)\end{array}$ & $\begin{array}{c}0.000 \\
(0.145)\end{array}$ & $\begin{array}{c}-0.002 \\
(-0.871)\end{array}$ \\
\hline Tangibility $_{t-1}$ & $\begin{array}{c}0.033 \\
(0.388)\end{array}$ & $\begin{array}{c}-0.017 \\
(-0.127)\end{array}$ & $\begin{array}{c}0.077 \\
(1.045)\end{array}$ & $\begin{array}{c}0.053 \\
(0.646)\end{array}$ & $\begin{array}{c}0.011 \\
(0.093)\end{array}$ & $\begin{array}{c}-0.004 \\
(-0.051)\end{array}$ \\
\hline $\operatorname{Ln}\left(\right.$ Assets $\left._{t-1}\right)$ & $\begin{array}{c}0.027^{* *} \\
(2.294)\end{array}$ & $\begin{array}{c}0.028^{*} \\
(1.795)\end{array}$ & $\begin{array}{c}0.017 \\
(1.434)\end{array}$ & $\begin{array}{c}0.007 \\
(1.058)\end{array}$ & $\begin{array}{c}0.012 \\
(1.115)\end{array}$ & $\begin{array}{c}0.016^{* *} \\
(2.221)\end{array}$ \\
\hline $\mathrm{ROA}_{t-1}$ & $\begin{array}{l}-0.844^{* * *} \\
(-4.792)\end{array}$ & $\begin{array}{l}-1.313^{* * *} \\
(-5.061)\end{array}$ & $\begin{array}{l}-0.855^{* * *} \\
(-3.915)\end{array}$ & $\begin{array}{c}-0.229^{* *} \\
(-2.530)\end{array}$ & $\begin{array}{c}-0.272^{*} \\
(-1.901)\end{array}$ & $\begin{array}{l}-0.280^{* *} \\
(-2.689)\end{array}$ \\
\hline Market-to-Book $_{t-1}$ & $\begin{array}{c}0.007 \\
(1.039)\end{array}$ & $\begin{array}{c}0.015 \\
(1.406)\end{array}$ & $\begin{array}{c}-0.022^{*} \\
(-1.728)\end{array}$ & $\begin{array}{c}0.001 \\
(0.374)\end{array}$ & $\begin{array}{c}0.001 \\
(0.325)\end{array}$ & $\begin{array}{c}-0.007^{* *} \\
(-2.510)\end{array}$ \\
\hline Observations & 567 & 567 & 567 & 546 & 546 & 546 \\
\hline Adj. R-squared & 0.665 & 0.705 & 0.753 & 0.230 & 0.236 & 0.469 \\
\hline Year FE & YES & YES & YES & YES & YES & YES \\
\hline Firm FE & YES & YES & YES & NO & NO & NO \\
\hline
\end{tabular}




\section{Table A3: Subsample Analysis - OECD Countries (Firm Panel)}

This table reports the firm-fixed effects and first differences estimation results for the baseline specification using the panel of OECD countries. All regressions include year-fixed effects. Standard errors are clustered at the country level. Statistical significance at the $10 \%, 5 \%$ and $1 \%$ levels are denoted by "**, "**" and "****, respectively.

\begin{tabular}{|c|c|c|c|c|c|c|}
\hline & \multicolumn{3}{|c|}{ Panel A: Fixed Effects } & \multicolumn{3}{|c|}{ Panel B: First Differences } \\
\hline & $\begin{array}{c}\text { Book } \\
\text { Leverage }\end{array}$ & $\begin{array}{c}\text { Debt-to- } \\
\text { Capital }\end{array}$ & $\begin{array}{c}\text { Market } \\
\text { Leverage }\end{array}$ & $\begin{array}{c}\text { Book } \\
\text { Leverage }\end{array}$ & $\begin{array}{c}\text { Debt-to- } \\
\text { Capital }\end{array}$ & $\begin{array}{c}\text { Market } \\
\text { Leverage }\end{array}$ \\
\hline Gov. Debt-to-GDP ${ }_{t-1}$ & $\begin{array}{l}-0.060^{* * *} \\
(-3.412)\end{array}$ & $\begin{array}{c}-0.061^{* *} \\
(-2.624)\end{array}$ & $\begin{array}{c}-0.050^{* *} \\
(-2.296)\end{array}$ & $\begin{array}{l}-0.106^{* * *} \\
(-4.066)\end{array}$ & $\begin{array}{l}-0.097^{* * *} \\
(-4.145)\end{array}$ & $\begin{array}{l}-0.093^{* * *} \\
(-3.223)\end{array}$ \\
\hline Ln(GDP Per Capita $\left.{ }_{t-1}\right)$ & $\begin{array}{c}-0.005 \\
(-0.387)\end{array}$ & $\begin{array}{c}-0.016 \\
(-0.770)\end{array}$ & $\begin{array}{c}0.015 \\
(1.031)\end{array}$ & $\begin{array}{c}0.031^{* * *} \\
(4.769)\end{array}$ & $\begin{array}{c}0.023^{* *} \\
(2.397)\end{array}$ & $\begin{array}{c}0.011 \\
(0.979)\end{array}$ \\
\hline $\operatorname{Ln}\left(\right.$ CPI Index Level $\left.{ }_{t-1}\right)$ & $\begin{array}{c}0.049 \\
(1.180)\end{array}$ & $\begin{array}{c}0.116^{*} \\
(1.988)\end{array}$ & $\begin{array}{c}0.016 \\
(0.348)\end{array}$ & $\begin{array}{c}0.065 \\
(0.689)\end{array}$ & $\begin{array}{c}0.046 \\
(0.606)\end{array}$ & $\begin{array}{c}-0.100^{*} \\
(-1.834)\end{array}$ \\
\hline $\operatorname{Ln}\left(\mathrm{S} \& \mathrm{P}\right.$ Index Level $\left.{ }_{t-1}\right)$ & $\begin{array}{l}-0.021^{* * *} \\
(-2.868)\end{array}$ & $\begin{array}{c}-0.023^{* *} \\
(-2.120)\end{array}$ & $\begin{array}{l}-0.053^{* * *} \\
(-6.403)\end{array}$ & $\begin{array}{c}-0.007 \\
(-1.577)\end{array}$ & $\begin{array}{c}-0.001 \\
(-0.200)\end{array}$ & $\begin{array}{c}-0.014 \\
(-1.432)\end{array}$ \\
\hline Unemployment Rate $_{t-1}$ & $\begin{array}{c}-0.077 \\
(-0.939)\end{array}$ & $\begin{array}{c}-0.130 \\
(-1.101)\end{array}$ & $\begin{array}{c}-0.117 \\
(-1.090)\end{array}$ & $\begin{array}{c}0.025 \\
(0.338)\end{array}$ & $\begin{array}{c}-0.072 \\
(-0.672)\end{array}$ & $\begin{array}{c}-0.161^{*} \\
(-1.826)\end{array}$ \\
\hline Ln(Exchange Rate Re $\left._{t-1}\right)$ & $\begin{array}{l}-0.009^{* * *} \\
(-3.294)\end{array}$ & $\begin{array}{l}-0.010^{* *} \\
(-2.183)\end{array}$ & $\begin{array}{c}-0.011^{* *} \\
(-2.707)\end{array}$ & $\begin{array}{l}-0.003^{* * *} \\
(-3.721)\end{array}$ & $\begin{array}{l}-0.004^{* * *} \\
(-4.075)\end{array}$ & $\begin{array}{c}-0.002 \\
(-1.144)\end{array}$ \\
\hline Tangibility $_{t-1}$ & $\begin{array}{l}0.121^{* * *} \\
(5.653)\end{array}$ & $\begin{array}{c}0.141^{* * *} \\
(4.595)\end{array}$ & $\begin{array}{c}0.098^{* * *} \\
(4.822)\end{array}$ & $\begin{array}{c}0.044^{* * *} \\
(4.498)\end{array}$ & $\begin{array}{c}0.053^{* * *} \\
(4.245)\end{array}$ & $\begin{array}{c}0.038^{* * *} \\
(4.906)\end{array}$ \\
\hline $\operatorname{Ln}\left(\right.$ Assets $\left._{t-1}\right)$ & $\begin{array}{l}0.032^{* * *} \\
(9.274)\end{array}$ & $\begin{array}{l}0.041^{* * *} \\
(8.724)\end{array}$ & $\begin{array}{c}0.038^{* * *} \\
(11.384)\end{array}$ & $\begin{array}{c}0.005^{* *} \\
(2.590)\end{array}$ & $\begin{array}{l}0.010^{* * *} \\
(7.000)\end{array}$ & $\begin{array}{l}0.019^{* * *} \\
(6.492)\end{array}$ \\
\hline $\mathrm{ROA}_{t-1}$ & $\begin{array}{l}-0.095^{* * *} \\
(-7.867)\end{array}$ & $\begin{array}{l}-0.088^{* * *} \\
(-5.820)\end{array}$ & $\begin{array}{l}-0.063^{* * *} \\
(-5.657)\end{array}$ & $\begin{array}{l}-0.030^{* * *} \\
(-4.377)\end{array}$ & $\begin{array}{l}-0.014^{* * *} \\
(-6.725)\end{array}$ & $\begin{array}{l}-0.013^{* * *} \\
(-8.901)\end{array}$ \\
\hline Market-to-Book ${ }_{t-1}$ & $\begin{array}{l}-0.004^{* * *} \\
(-4.255)\end{array}$ & $\begin{array}{l}-0.006^{* * *} \\
(-3.385)\end{array}$ & $\begin{array}{c}-0.009^{* * *} \\
(-10.371)\end{array}$ & $\begin{array}{l}-0.001^{* * *} \\
(-3.399)\end{array}$ & $\begin{array}{l}-0.002^{* * *} \\
(-5.526)\end{array}$ & $\begin{array}{c}0.001^{* *} \\
(2.591)\end{array}$ \\
\hline Observations & 273,291 & 267,165 & 263,410 & 239,021 & 234,347 & 230,985 \\
\hline Adj. R-squared & 0.629 & 0.702 & 0.724 & 0.0121 & 0.0123 & 0.0606 \\
\hline Year FE & YES & YES & YES & YES & YES & YES \\
\hline Firm FE & YES & YES & YES & NO & NO & NO \\
\hline
\end{tabular}




\section{Table A4: External Debt (Firm Panel)}

This table investigates the impact of external government debt on corporate leverage by repeating both the firm-fixed effects and the first differences specifications after decomposing Government Debt-to-GDP as Domestic Government Debt and External Government Debt measured in percent of GDP. External Government Debt is government debt owed to nonresidents. Domestic Government Debt is Government Debt-to-GDP net of external debt. Standard errors are clustered at the country level. Statistical significance at the $10 \%, 5 \%$ and $1 \%$ levels are denoted by "**", "**" and "***", respectively.

\begin{tabular}{|c|c|c|c|c|c|c|}
\hline & \multicolumn{3}{|c|}{ Panel A: Fixed Effects } & \multicolumn{3}{|c|}{ Panel B: First Differences } \\
\hline & $\begin{array}{c}\text { Book } \\
\text { Leverage }\end{array}$ & $\begin{array}{l}\text { Debt-to- } \\
\text { Capital }\end{array}$ & $\begin{array}{l}\text { Market } \\
\text { Leverage }\end{array}$ & $\begin{array}{c}\text { Book } \\
\text { Leverage }\end{array}$ & $\begin{array}{l}\text { Debt-to- } \\
\text { Capital }\end{array}$ & $\begin{array}{l}\text { Market } \\
\text { Leverage }\end{array}$ \\
\hline Domestic Gov. Debt $t_{t-1}$ & $\begin{array}{c}-0.039^{* *} \\
(-2.198)\end{array}$ & $\begin{array}{c}-0.037 \\
(-1.424)\end{array}$ & $\begin{array}{l}-0.049^{* *} \\
(-2.113)\end{array}$ & $\begin{array}{l}-0.072^{* * *} \\
(-2.784)\end{array}$ & $\begin{array}{l}-0.089^{* * *} \\
(-3.945)\end{array}$ & $\begin{array}{l}-0.051^{* * *} \\
(-2.806)\end{array}$ \\
\hline External Gov. Debt $t_{t-1}$ & $\begin{array}{c}0.020 \\
(0.515)\end{array}$ & $\begin{array}{c}0.010 \\
(0.198)\end{array}$ & $\begin{array}{c}0.048 \\
(1.052)\end{array}$ & $\begin{array}{c}-0.001 \\
(-0.035)\end{array}$ & $\begin{array}{c}-0.016 \\
(-0.426)\end{array}$ & $\begin{array}{c}-0.022 \\
(-0.519)\end{array}$ \\
\hline Ln(GDP Per Capita C $\left._{t-1}\right)$ & $\begin{array}{l}-0.025^{* * *} \\
(-3.054)\end{array}$ & $\begin{array}{c}-0.022^{*} \\
(-1.792)\end{array}$ & $\begin{array}{c}-0.018 \\
(-1.345)\end{array}$ & $\begin{array}{c}0.011 \\
(0.796)\end{array}$ & $\begin{array}{c}0.009 \\
(0.871)\end{array}$ & $\begin{array}{c}-0.003 \\
(-0.135)\end{array}$ \\
\hline Ln(CPI Index Level $\left.{ }_{t-1}\right)$ & $\begin{array}{c}0.031 \\
(1.278)\end{array}$ & $\begin{array}{c}0.052 \\
(1.445)\end{array}$ & $\begin{array}{c}0.024 \\
(0.830)\end{array}$ & $\begin{array}{c}-0.015 \\
(-0.281)\end{array}$ & $\begin{array}{c}-0.015 \\
(-0.318)\end{array}$ & $\begin{array}{c}0.015 \\
(0.368)\end{array}$ \\
\hline $\operatorname{Ln}\left(\mathrm{S} \& \mathrm{P}\right.$ Index Level $\left.{ }_{t-1}\right)$ & $\begin{array}{c}-0.010^{*} \\
(-1.718)\end{array}$ & $\begin{array}{c}-0.013 \\
(-1.522)\end{array}$ & $\begin{array}{l}-0.030^{* * *} \\
(-4.044)\end{array}$ & $\begin{array}{l}-0.005^{* *} \\
(-2.146)\end{array}$ & $\begin{array}{c}-0.004 \\
(-1.048)\end{array}$ & $\begin{array}{c}-0.000 \\
(-0.034)\end{array}$ \\
\hline Unemployment Rate $_{t-1}$ & $\begin{array}{c}-0.084 \\
(-0.889)\end{array}$ & $\begin{array}{c}-0.038 \\
(-0.334)\end{array}$ & $\begin{array}{c}-0.268 \\
(-1.668)\end{array}$ & $\begin{array}{c}0.024 \\
(0.230)\end{array}$ & $\begin{array}{c}-0.045 \\
(-0.362)\end{array}$ & $\begin{array}{l}-0.215^{*} \\
(-1.789)\end{array}$ \\
\hline Ln(Exchange Rate E $\left._{t-1}\right)$ & $\begin{array}{l}-0.008^{* * *} \\
(-3.017)\end{array}$ & $\begin{array}{c}-0.009^{* *} \\
(-2.166)\end{array}$ & $\begin{array}{c}-0.008^{* *} \\
(-2.236)\end{array}$ & $\begin{array}{l}-0.002^{* *} \\
(-2.190)\end{array}$ & $\begin{array}{l}-0.003^{* * *} \\
(-3.682)\end{array}$ & $\begin{array}{c}-0.002 \\
(-0.788)\end{array}$ \\
\hline Tangibility $_{t-1}$ & $\begin{array}{c}0.130^{* * *} \\
(7.698)\end{array}$ & $\begin{array}{l}0.154^{* * *} \\
(6.058)\end{array}$ & $\begin{array}{c}0.101^{* * *} \\
(5.988)\end{array}$ & $\begin{array}{c}0.042^{* * *} \\
(5.117)\end{array}$ & $\begin{array}{c}0.051^{* * *} \\
(4.775)\end{array}$ & $\begin{array}{l}0.035^{* * *} \\
(5.053)\end{array}$ \\
\hline $\operatorname{Ln}\left(\right.$ Assets $\left._{t-1}\right)$ & $\begin{array}{l}0.035^{* * *} \\
(8.257)\end{array}$ & $\begin{array}{l}0.045^{* * *} \\
(7.402)\end{array}$ & $\begin{array}{c}0.041^{* * *} \\
(10.051)\end{array}$ & $\begin{array}{l}0.005^{* * *} \\
(2.929)\end{array}$ & $\begin{array}{l}0.011^{* * *} \\
(7.934)\end{array}$ & $\begin{array}{l}0.020^{* * *} \\
(7.371)\end{array}$ \\
\hline $\mathrm{ROA}_{t-1}$ & $\begin{array}{l}-0.098^{* * *} \\
(-8.317)\end{array}$ & $\begin{array}{l}-0.093^{* * *} \\
(-5.935)\end{array}$ & $\begin{array}{c}-0.068^{* * *} \\
(-5.794)\end{array}$ & $\begin{array}{l}-0.031^{* * *} \\
(-4.996)\end{array}$ & $\begin{array}{l}-0.015^{* * *} \\
(-6.246)\end{array}$ & $\begin{array}{l}-0.014^{* * *} \\
(-8.205)\end{array}$ \\
\hline Market-to-Book ${ }_{t-1}$ & $\begin{array}{l}-0.004^{* * *} \\
(-2.916)\end{array}$ & $\begin{array}{l}-0.005^{* *} \\
(-2.284)\end{array}$ & $\begin{array}{c}-0.009^{* * *} \\
(-10.697)\end{array}$ & $\begin{array}{l}-0.001^{* * *} \\
(-2.848)\end{array}$ & $\begin{array}{l}-0.002^{* * *} \\
(-4.098)\end{array}$ & $\begin{array}{l}0.001^{* * *} \\
(3.202)\end{array}$ \\
\hline Observations & 294,821 & 288,513 & 282,841 & 252,956 & 248,124 & 243,030 \\
\hline Adj. R-squared & 0.635 & 0.707 & 0.732 & 0.009 & 0.011 & 0.066 \\
\hline Year FE & YES & YES & YES & YES & YES & YES \\
\hline Firm FE & YES & YES & YES & $\mathrm{NO}$ & $\mathrm{NO}$ & $\mathrm{NO}$ \\
\hline
\end{tabular}




\section{Table A5: Debt Maturity}

This table reports the results from fixed effects and first differences regressions of Long-Term Debt and Short-Term Debt as well as their ratio. Long-Term Debt is total debt due in more than one year. ShortTerm Debt is debt in current liabilities. Standard errors are clustered at the country level. Statistical significance at the $10 \%, 5 \%$ and $1 \%$ levels are denoted by "**, "**" and "***", respectively.

\begin{tabular}{|c|c|c|c|c|c|c|}
\hline & \multicolumn{3}{|c|}{ Panel A: Fixed Effects } & \multicolumn{3}{|c|}{ Panel B: First Differences } \\
\hline & $\begin{array}{c}\text { Long-Term } \\
\text { Debt to } \\
\text { Assets }\end{array}$ & $\begin{array}{c}\text { Short-Term } \\
\text { Debt to } \\
\text { Assets }\end{array}$ & $\begin{array}{c}\text { Long- to } \\
\text { Short-Term } \\
\text { Debt }\end{array}$ & $\begin{array}{c}\text { Long-Term } \\
\text { Debt to } \\
\text { Assets }\end{array}$ & $\begin{array}{c}\text { Short-Term } \\
\text { Debt to } \\
\text { Assets }\end{array}$ & $\begin{array}{c}\text { Long- to } \\
\text { Short-Term } \\
\text { Debt }\end{array}$ \\
\hline Gov. Debt-to-GDP ${ }_{t-1}$ & $\begin{array}{c}-0.031^{*} \\
(-1.955)\end{array}$ & $\begin{array}{l}-0.034^{* * *} \\
(-3.569)\end{array}$ & $\begin{array}{c}-0.032 \\
(-0.679)\end{array}$ & $\begin{array}{l}-0.044^{* * *} \\
(-3.325)\end{array}$ & $\begin{array}{l}-0.056^{* * *} \\
(-3.482)\end{array}$ & $\begin{array}{c}-0.003 \\
(-0.153)\end{array}$ \\
\hline Ln(GDP Per Capita Cl-1 $)$ & $\begin{array}{c}-0.017 \\
(-1.268)\end{array}$ & $\begin{array}{l}-0.010 \\
(-0.627)\end{array}$ & $\begin{array}{c}-0.024 \\
(-0.572)\end{array}$ & $\begin{array}{c}-0.004 \\
(-1.075)\end{array}$ & $\begin{array}{c}0.008 \\
(0.784)\end{array}$ & $\begin{array}{c}-0.012 \\
(-0.474)\end{array}$ \\
\hline Ln(CPI Index Level $t-1)$ & $\begin{array}{c}-0.029 \\
(-0.654)\end{array}$ & $\begin{array}{c}0.043 \\
(1.416)\end{array}$ & $\begin{array}{c}-0.138 \\
(-1.026)\end{array}$ & $\begin{array}{c}-0.045 \\
(-1.380)\end{array}$ & $\begin{array}{c}-0.008 \\
(-0.416)\end{array}$ & $\begin{array}{c}-0.079 \\
(-0.985)\end{array}$ \\
\hline $\operatorname{Ln}\left(\mathrm{S} \& \mathrm{P}\right.$ Index Level $\left._{t-1}\right)$ & $\begin{array}{c}-0.001 \\
(-0.159)\end{array}$ & $\begin{array}{l}-0.015^{* * *} \\
(-4.154)\end{array}$ & $\begin{array}{c}0.015 \\
(1.192)\end{array}$ & $\begin{array}{c}0.001 \\
(0.361)\end{array}$ & $\begin{array}{c}-0.005^{*} \\
(-1.889)\end{array}$ & $\begin{array}{c}-0.000 \\
(-0.103)\end{array}$ \\
\hline Unemployment Rate $_{t-1}$ & $\begin{array}{c}-0.024 \\
(-0.281)\end{array}$ & $\begin{array}{c}0.037 \\
(0.512)\end{array}$ & $\begin{array}{c}0.075 \\
(0.294)\end{array}$ & $\begin{array}{l}-0.112^{* *} \\
(-2.100)\end{array}$ & $\begin{array}{c}0.113 \\
(1.500)\end{array}$ & $\begin{array}{c}-0.072 \\
(-0.364)\end{array}$ \\
\hline Ln(Exchange Rate E $\left._{t-1}\right)$ & $\begin{array}{l}-0.007^{* * *} \\
(-3.078)\end{array}$ & $\begin{array}{l}-0.003^{* *} \\
(-2.220)\end{array}$ & $\begin{array}{l}-0.009^{*} \\
(-1.995)\end{array}$ & $\begin{array}{l}-0.003^{* * *} \\
(-3.616)\end{array}$ & $\begin{array}{c}-0.000 \\
(-0.616)\end{array}$ & $\begin{array}{c}-0.004^{*} \\
(-1.969)\end{array}$ \\
\hline Tangibility $_{t-1}$ & $\begin{array}{l}0.078^{* * *} \\
(5.105)\end{array}$ & $\begin{array}{c}0.045^{* * *} \\
(12.094)\end{array}$ & $\begin{array}{l}0.067^{* * *} \\
(3.915)\end{array}$ & $\begin{array}{c}0.014^{* *} \\
(2.271)\end{array}$ & $\begin{array}{l}0.029^{* * *} \\
(9.086)\end{array}$ & $\begin{array}{l}-0.028^{* * *} \\
(-3.000)\end{array}$ \\
\hline $\operatorname{Ln}\left(\operatorname{Assets}_{t-1}\right)$ & $\begin{array}{c}0.027^{* * *} \\
(14.444)\end{array}$ & $\begin{array}{c}0.010^{* *} \\
(2.533)\end{array}$ & $\begin{array}{c}0.037^{* * *} \\
(22.127)\end{array}$ & $\begin{array}{l}0.005^{* * *} \\
(5.305)\end{array}$ & $\begin{array}{c}0.002 \\
(1.441)\end{array}$ & $\begin{array}{l}0.007^{* * *} \\
(2.896)\end{array}$ \\
\hline $\mathrm{ROA}_{t-1}$ & $\begin{array}{l}-0.044^{* * *} \\
(-8.122)\end{array}$ & $\begin{array}{l}-0.051^{* * *} \\
(-6.080)\end{array}$ & $\begin{array}{c}0.021^{* *} \\
(2.032)\end{array}$ & $\begin{array}{l}-0.012^{* * *} \\
(-6.809)\end{array}$ & $\begin{array}{l}-0.014^{* * *} \\
(-3.945)\end{array}$ & $\begin{array}{c}-0.006 \\
(-0.993)\end{array}$ \\
\hline Market-to-Book ${ }_{t-1}$ & $\begin{array}{c}-0.001 \\
(-1.283)\end{array}$ & $\begin{array}{l}-0.003^{* * *} \\
(-7.472)\end{array}$ & $\begin{array}{l}0.004^{* * *} \\
(4.301)\end{array}$ & $\begin{array}{l}-0.001^{* *} \\
(-2.078)\end{array}$ & $\begin{array}{l}-0.001^{* * *} \\
(-3.236)\end{array}$ & $\begin{array}{c}0.001 \\
(1.449)\end{array}$ \\
\hline Observations & 343,403 & 343,403 & 295,318 & 299,034 & 299,116 & 249,865 \\
\hline Adj. R-squared & 0.629 & 0.556 & 0.542 & 0.004 & 0.005 & 0.001 \\
\hline Year FE & YES & YES & YES & YES & YES & YES \\
\hline Firm FE & YES & YES & YES & NO & NO & NO \\
\hline
\end{tabular}

